NBER WORKING PAPER SERIES

\title{
MEASURING INVESTMENT DISTORTIONS WHEN RISK-AVERSE MANAGERS DECIDE WHETHER TO UNDERTAKE RISKY PROJECTS
}

\author{
Robert Parrino \\ Allen M. Poteshman \\ Michael S. Weisbach \\ Working Paper 8763 \\ http://www.nber.org/papers/w8763 \\ NATIONAL BUREAU OF ECONOMIC RESEARCH \\ 1050 Massachusetts Avenue \\ Cambridge, MA 02138 \\ February 2002
}

We would like to thank Jennifer Carpenter, Ludger Hentschel, Kose John, Anthony Lynch, Bob McDonald, Lisa Meulbroek, Erwan Morellec, Neil Pearson, Peter Tufano and seminar participants at University of Arizona, University of Kansas, Loyola University, New York University, the New York Federal Reserve Bank, NBER, Ohio State University, University of Rochester, University of Southern California, Texas A\&M University, and University of Texas at Dallas for helpful suggestions, and Sergey Tsyplakov for excellent research assistance. The views expressed herein are those of the authors and not necessarily those of the National Bureau of Economic Research.

(C) 2002 by Robert Parrino, Allen M. Poteshman and Michael S. Weisbach. All rights reserved. Short sections of text, not to exceed two paragraphs, may be quoted without explicit permission provided that full credit, including $(\mathbb{C}$ notice, is given to the source. 
Measuring Investment Distortions when Risk-Averse Managers Decide

Whether to Undertake Risky Projects

Robert Parrino, Allen M. Poteshman and Michael S. Weisbach

NBER Working Paper No. 8763

February 2002

JEL No. G3, H2

\begin{abstract}
$\underline{\text { ABSTRACT }}$
This paper examines distortions in corporate investment decisions when a new project changes firm risk. It presents a dynamic model in which a self-interested, risk-averse manager makes investment decisions at a levered firm. The model, calibrated using data from public firms, is used to estimate the magnitude of distortions in investment decisions. Despite potential wealth transfers from debtholders, managers compensated with equity prefer safe projects to risky ones. Important factors in this decision are the expected changes in the values of future tax shields and bankruptcy costs when firm risk changes. We also evaluate the extent to which this effect varies with firm leverage, managerial risk aversion, managerial non-firm wealth, project size, debt duration, and the structure of management compensation packages.
\end{abstract}

Robert Parrino

Department of Finance

McCombs School of Business

University of Texas at Austin

Austin, TX 78712-1179

Tel: 512-471-5788

Email: Parrino@mail.utexas.edu
Allen M. Poteshman

Department of Finance

College of Commerce and

Business Administration

University of Illinois

Champaign, IL 61820

Tel: 217-265-0565

Email: Poteshma@uiuc.edu
Michael S. Weisbach

Department of Finance

College of Commerce and

Business Administration

University of Illinois

Champaign, IL 61820

and NBER

Tel: 217-265-0258

Email: Weisbach@uiuc.edu 


\section{Measuring Investment Distortions when Risk-Averse Managers Decide Whether to Undertake Risky Projects}

Distortions in investment decisions resulting from conflicts of interest between claimholders have been modeled extensively in the corporate finance literature. These models generally imply that firms make sub-optimal project choices, either in terms of good projects that are rejected, or bad projects that are accepted. Since it is difficult to observe management forecasts of project net present values, especially for projects that are not ultimately undertaken, it is difficult to assess the importance of these models quantitatively.

One approach to evaluating the importance of investment distortions is to calibrate a model using real-world data and then to estimate the magnitude of the distortion in investment decisions by examining the characteristics of the projects that the model predicts would be accepted or rejected. This approach has been used to estimate the magnitude of the impact of stockholder/debtholder conflicts on investment decisions (Mello and Parsons (1992), Leland (1998), Parrino and Weisbach (1999), and Moyen (2000)). Papers that examine stockholder/debtholder conflicts in this way typically assume that managers maximize the value of the firms' stock (i.e., they assume away any conflict of interest between managers and stockholders).

In this paper, we relax this assumption and estimate the magnitude of stockholder/manager conflicts, their interactions with stockholder/debtholder conflicts, and their effect on a firm's investment decisions. In particular, we consider a risk-averse manager who makes a firm's investment decisions while seeking to maximize his own utility function. In our model, the manager owns shares in a levered firm (which he cannot hedge), options on the firm's stock, and has other wealth that is independent of the value of that firm. The firm is modeled using the dynamic approach of Ju (2001), in which new debt is issued when old debt matures, the firm enters bankruptcy if its value hits a pre-specified bankruptcy boundary, and interest payments are fully deductible in computing corporate taxes. The manager has the option to undertake a project that would alter the firm's value process. If the firm defaults on its debt, the 
stock owned by the manager (and other shareholders) becomes worthless and the debtholders recover a fixed percentage of the remaining value of the firm.

We first estimate the magnitude of these conflicts for a hypothetical firm, constructed to be typical of publicly traded firms on the Standard and Poor's Compustat database. Before adopting the project, the firm is financed with ten-year coupon-bearing debt and has a market debt to total capital ratio of 21.90 percent. We assume that the manager has a constant relative risk aversion (CRRA) utility function with a risk aversion parameter of 2 and has 50 percent of his non-option wealth invested in shares of the firm, with the remainder invested in risk-free assets. The value of the project's assets (e.g., the value of the cash flows from operations) is assumed to equal 20 percent of the value of the firm's assets without the project. We vary the volatility of the value of the assets of the firm with the project holding other factors constant to determine the effects of incremental changes in risk.

We assume that the manager is considering a project that changes the risk of the firm. For any potential project, we calculate its impact on the value of stockholder and debtholder claims, as well as the manager's utility. In doing so, we calculate explicitly the changes in the values of the firm's future tax shields and the expected bankruptcy costs. We characterize the magnitude of stockholder/manager conflicts arising from manager risk-aversion by estimating the net present value (NPV) of the project that makes the manager indifferent to accepting or rejecting it. We also compute the implied incremental (relative to that required for a zero NPV project) cost of equity that makes the manager indifferent. The mapping between the indifference NPV and the incremental rate of return with the risk of the project provides a measure of managerial aversion to project risk, once all factors are considered.

We find that, in contrast to the usual arguments in the literature, a manager compensated entirely with equity-based compensation is likely to favor projects that lower firm risk. In other words, he will want to undertake some projects that lower firm risk even if they have a negative NPV, and to ignore some high-risk projects despite the fact that they have a positive NPV. This effect occurs even though risky projects transfer wealth from debtholders to stockholders. Managerial risk aversion is of course one 
factor determining this negative attitude toward risk. However, in our model, even a risk-neutral stockholder will prefer that the firm distort investment decisions towards safe and away from risky projects. The stockholder displays this preference because the values of the firm's tax shields and expected bankruptcy costs (which are borne in part by stockholders since existing debt is replaced with fairly-priced new debt when it matures) change with risk. Our estimates suggest that the changes in the values of tax shields and bankruptcy costs at a typical firm are more than sufficient to offset the wealth transfer and option effects, leading to risk-averse investment behavior by managers.

It is often argued that managers' incentives to take risks increase substantially with firm leverage, because wealth transfers between stockholders and debtholders increase with leverage (see Myers (1977)). In our model, wealth transfers do increase with leverage. However, the values of tax shields and bankruptcy costs are also more sensitive to changes in risk when leverage is higher. The overall relation between leverage and risk-taking behavior appears to be nonlinear: When leverage is low, managers have a preference for safe projects. However, at high leverage ratios, the wealth transfer effect dominates, and managers have incentives to take negative NPV projects that increase firm risk.

We also consider the sensitivity of these results to variation in the parameters. First, we find that the magnitude of the stockholder/manager distortions is very sensitive to the choice of the risk aversion parameter. Second, we vary the fraction of the manager's wealth invested in the firm. Changes in the fraction of non-firm wealth have an effect similar to changes in the risk aversion parameter; equity in the firm owned by managers with high outside wealth represents a relatively low share of their total wealth, so they are less sensitive to changes in its value. Third, we find that larger projects exacerbate the distortions attributable to stockholder/manager conflicts. Fourth, the distortions in investment decisions decrease with the duration of the firm's debt because the larger wealth transfers associated with longer maturity debt offset the preference for relatively safe projects to a greater extent. Fifth, we examine the structure of management compensation and its impact on risk-taking behavior. In our model, not surprisingly, options induce better (from the perspective of stockholders) risk-taking behavior than 
restricted stock, and options that are issued in-the-money make managers' substantially more risk averse than options issued with exercise prices equal to or greater than the current market price of the firm's stock.

In addition to estimating the magnitudes of investment distortions for a hypothetical firm, we use our model to estimate these distortions at 15 public firms from three industries. These estimates, based on actual CEO equity-based compensation and firm characteristics in this sample, reveal that, with the exception of one firm, CEOs with a risk aversion parameter of 2 will prefer to reject some positive NPV projects that have asset values that are less than twice as volatile as the asset values of their firms. This evidence suggests that managers can have little incentive to invest in highly risky projects even when they receive relatively large amounts of option-based compensation.

This paper focuses on conflicts due to differences in risk aversion. Zingales (2000) suggests that these effects are understudied and potentially important considerations in corporate financing decisions. While we focus on managerial risk aversion, we do not wish to downplay the importance of other stockholder/manager conflicts. In addition to the risk-related reasons considered here, conflicts between stockholders and managers arise because of a tendency of managers to empire-build, concerns about a manager's human capital both inside and outside of the firm, a tendency to focus on short term objectives, a propensity to herd and not utilize private information about a project's quality, a preference for an easy job, and finally, overconfidence. Stein (2001) provides an excellent summary of these considerations.

The remainder of this paper is organized as follows: Section I describes the construction and solution of the model. Section II explains how it is calibrated. Section III discusses implications of the model for investment decisions at a typical firm, and Section IV discusses the implications for a sample of public firms. Section V summarizes the results and discusses the extent to which stockholder/manager problems of the type considered in this paper are likely to have an important impact on corporate financial decisions. 


\section{The Models}

We use models based on Ju (2001) to estimate the magnitudes of the agency conflicts discussed above. In these models, the value of the cash flows from a firm's operations follows geometric Brownian motion, and the firm issues debt with a maturity of $T$, which pays a continuous, constant (tax-deductible) coupon. The manager's wealth at time zero is divided between non-firm wealth and his stake in the firm, which consists of equity shares and standard European call options, which expire at time $T_{u}$. The manager cannot sell or hedge his shares or options. For simplicity, it is assumed that the manager's nonfirm wealth grows at the risk-free rate, $r$, and is therefore uncorrelated with the value of the manager's stake in the firm. The manager's utility is given by a CRRA utility function defined over his entire wealth.

At time zero the manager has the opportunity to undertake a project. Without the project, the value process of the firm's assets (i.e., the value of the cash flows from operations) follows geometric Brownian motion. If the manager accepts the project, the value process of the assets still follows geometric Brownian motion but with drift and volatility parameters that can differ from those without the project, depending on the characteristics of the project. The manager decides whether to accept the project by maximizing, at time zero, his expected utility at time $T_{u}$.

The model is in continuous time with $0<T_{u}<T$. At time zero, the value of the firm's assets

without the project is $V_{N P}(0) .{ }^{1}$ The firm's capital consists of (1) $N_{N P}$ shares of stock with a total market value of $E_{N P}(0)$ and (2) $F_{N P}$ face value of debt that matures at time $T$. The debt pays a coupon at a constant annualized rate $C_{N P}$ and has a market value of $D_{N P}(0)$. The coupon rate $C_{N P}$ is set so that, without the project, the debt is priced at par. The firm deducts its coupon payments when computing its taxes, at an effective rate $\tau$, and the tax benefit of the debt at time zero has a value $T B_{N P}(0)$. The

\footnotetext{
${ }^{1}$ The subscript $N P$ refers to quantities when the project is not taken (no project) and the subscript $P$ refers to quantities when the project is taken (project).
} 
debt has a protective covenant which specifies that if the firm value at anytime during the life of the debt $[0, T]$ decreases to an exponential boundary, the firm is forced into bankruptcy. ${ }^{2}$ When this occurs, the stock becomes worthless and the debtholders recover $1-\alpha_{B C}$ of the value of the assets. The fraction of the value of the assets not recovered by the debtholders is assumed to be consumed in the bankruptcy process. The bankruptcy boundary is an exponential curve that increases at a rate $g$ and is equal to the face value of debt at time $T$. Consequently, without the project the bankruptcy boundary is described by $F_{N P} e^{g(t-T)}$. The bankruptcy costs for the firm are the present value of the expected losses in bankruptcy, and are denoted by $B C_{N P}(0)$.

The value of the firm's assets plus the tax benefit of debt equals the value of the debt plus the equity plus the bankruptcy costs:

$$
V_{N P}(0)+T B_{N P}(0)=D_{N P}(0)+E_{N P}(0)+B C_{N P}(0)
$$

If the firm does not accept the project at time zero, then the value of the firm's assets, $V_{N P}(t)$, follows geometric Brownian motion described by:

$$
\frac{d V_{N P}(t)}{V_{N P}(t)}=\left(\mu_{N P}-\delta\right) d t+\sigma_{N P} d Z(t)
$$

where $\mu_{N P}$ and $\sigma_{N P}>0$ are constants and $d Z(t)$ is a standard Weiner process. The firm liquidates assets at a rate of $\delta$ of the total value of the firm's assets, so that $\delta V_{N P}(t) d t$ equals the sum of the aftertax coupon paid to debtholders $\left[(1-\tau) C_{N P} d t\right]$ and a time varying dividend DivRate $(t) d t$ paid to equity holders over the time interval $d t$ :

$$
\delta V_{N P}(t) d t=\left[\operatorname{DivRate}(t)+(1-\tau) C_{N P}\right] d t
$$

\footnotetext{
${ }^{2} \mathrm{We}$ are implicitly assuming here that this covenant acts somewhat like the actual covenants seen in bond indenture agreements. These covenants are designed to enable debtholders to seize assets when they are in danger of being lost - our assumption models this process explicitly. See Black and Cox (1976) and Ju (2001) for other papers using this approach.
} 
In order to guarantee that the dividend rate is non-negative, we require that

$$
\delta V_{N P}(t) \geq(1-\tau) C_{N P}
$$

The value of $\delta$ is specified exogenously as a model parameter.

At time zero a project costing $\operatorname{COST}_{P}$ becomes available. If the manager accepts this project, the value of the assets becomes $V_{P}(0)$. This implies that (ignoring the impact on bankruptcy costs and tax benefits if the firm adopts the project) the NPV of the project is given by:

$$
N P V=V_{P}(0)-V_{N P}(0)-C O S T_{P}
$$

If the project is taken, the value of the assets, $V_{P}(t)$, follows geometric Brownian motion described by:

$$
\frac{d V_{P}(t)}{V_{P}(t)}=\left(\mu_{P}-\delta\right) d t+\sigma_{P} d Z(t)
$$

where $\mu_{P}$ and $\sigma_{P}>0$ are constants. Consequently, if the project is accepted the net impact on the current and future value of the firm's assets is to change the value of these assets at time zero from $V_{N P}(0)$ to $V_{P}(0)$ and to change the parameters of the geometric Brownian motion obeyed by the assets from $\mu_{N P}$ to $\mu_{P}$ and $\sigma_{N P}$ to $\sigma_{P}$. The firm still liquidates assets at a rate $\delta$.

If the manager does not accept the project, the capital structure of the firm does not change. If the project is accepted, it is financed with fairly priced debt and equity. Any new debt that is issued has exactly the same characteristics as the old debt (i.e., it has the same priority, pays a coupon that is the same percentage of the face value, and has time $T$ to maturity.) Let $N_{P}$ be the number of shares outstanding, $F_{P}$ the face value of debt outstanding, and $C_{P}$ the constant annualized coupon rate paid after the project is financed. Then

$$
C_{P}=C_{N P}\left(F_{P} / F_{N P}\right)
$$




$$
\operatorname{COST}_{P}=\left(\frac{N_{P}-N_{N P}}{N_{P}}\right) E_{P}(0)+\left(\frac{F_{P}-F_{N P}}{F_{P}}\right) D_{P}(0)
$$

and the value of the firm's assets becomes

$$
V_{P}(0)=D_{P}(0)+E_{P}(0)+B C_{P}(0)-T B_{P}(0)
$$

where $D_{P}(0), E_{P}(0), B C_{P}(0)$, and $T B_{P}(0)$ are the time zero values of debt, equity, bankruptcy costs, and tax benefit to debt respectively, when the manager accepts the project.

To solve the model, we must choose how the project is financed. We specify three alternative financing rules: The first financing rule holds the firm's market debt/total capital ratio fixed, so that:

$$
\frac{D_{N P}(0)}{D_{N P}(0)+E_{N P}(0)}=\frac{D_{P}(0)}{D_{P}(0)+E_{P}(0)}
$$

Under the second financing rule, the firm is required to finance the project using quantities of new debt and equity so that the market value of each dollar of face value of the debt does not change:

$$
\frac{D_{P}(0)}{F_{P}}=\frac{D_{N P}(0)}{F_{N P}}
$$

The final version of the model requires that the ratio of the market values of the newly issued debt to equity is the same as the ratio of the market values of the debt to equity before the project is adopted:

$$
\left(\frac{F_{P}-F_{N P}}{F_{P}}\right) D_{P}(0) /\left(\frac{N_{P}-N_{N P}}{N_{P}}\right) E_{P}(0)=\frac{D_{N P}(0)}{E_{N P}(0)}
$$

The financing rule matters because potential projects will affect the firm's total risk, and also, therefore, the relative values of its securities. For example, consider a project that substantially increases a firm's risk. With such a project, in order to obey the financing rule keeping the market debt to equity ratio constant (equation (10)), the project will have to be financed with a disproportionately large fraction of debt, since the value of existing debt will decrease with the addition of a risky project. Unfortunately, this is not particularly realistic, since risky projects are typically financed with relatively more equity. In 
contrast, equation (11), which holds the value of the outstanding debt constant, would require the firm to retire some existing debt so that current debtholders would remain whole. Again, this is not consistent with the way that firms usually finance projects. The third rule, which constrains the firm to issue new securities in the same proportion as the pre-project relative values of old securities (equation (12)), is perhaps the most realistic of the three. We therefore use this financing rule as our "base case". We present some results using the other rules as well, because it is informative to see which projects are attractive to the manager when accepting them does not change the leverage of the firm or the well being of the current debtholders.

At time zero the manager's stake in the firm consists of $N_{\text {Man }}\left(<N_{N P}\right)$ shares and $N_{\text {Calls }}$ European call options with strike price $K$ that expire at time $T_{u}$. For purposes of computational tractability, we assume that the firm buys the shares necessary to facilitate exercise of the manager's calls from a third party. Hence, if the manager exercises the calls at time $T_{u}$, he effectively buys $N_{\text {Calls }}$ shares from the third party at a price of $N_{\text {Calls }} K$ dollars. ${ }^{3}$ We assume that the manager cannot sell or hedge either his shares or his options. In addition, at time zero the manager has $N F W(0)$ dollars of non-firm wealth. For simplicity, this wealth is assumed to grow at the risk-free rate. The manager decides whether to accept the project at time zero by maximizing his expected utility at time $T_{u}$, which is described by

$$
U\left(\text { Wealth }_{T_{u}}\right)=\frac{\left(\text { Wealth }_{T_{u}}\right)^{1-\gamma}-1}{1-\gamma}
$$

where $\gamma$ is a risk-aversion parameter and Wealth $_{T_{u}}$ is the manager's total wealth at time $T_{u}$.

\footnotetext{
${ }^{3}$ We have also formulated and solved the model for the situation in which the manager's options are issued directly by the firm. In this case, if the manager exercises his options, the firm issues $N_{\text {Calls }}$ new shares of stock, which are given to the manager, and the manager pays $N_{\text {Calls }} K$ to the firm, which is invested in a scaling project. It took on the order of 10,000 times longer to compute solutions to this version of the model. Consequently, it would not be feasible to provide the analysis presented below with these types of options. We believe, however, that the results would be similar for the model with this alternative type of managerial options.
} 
The value of the debt, the bankruptcy costs, and the tax benefit of debt are computed from the probability density function for first hitting the exponential bankruptcy boundary. Let $f\left(t^{*} ; V(0), A, g, r, \delta, \sigma\right)$ be the probability density for first hitting a boundary described by $A e^{g t}$ at a time $t^{*}$, where $A$ is a constant, if the variable $V$ initially has a value $V(0)>A$ and follows geometric Brownian motion with drift $r-\delta$ and volatility $\sigma$. In our model, $A$ is the value of the bankruptcy boundary at time zero, so that $A$ is equal to $F_{N P} e^{-g T}$ if the project is foregone and is equal to $F_{P} e^{-g T}$ if the project is accepted. An explicit expression for $f\left(t^{*} ; V(0), A, g, r, \delta, \sigma\right)$ is provided in $\mathrm{Ju}(2001)$. Next define:

$$
\begin{gathered}
G(T, V(0), A, g, r, \delta, \sigma) \equiv \int_{0}^{T} f\left(t^{*} ; V(0), A, g, r, \delta, \sigma\right) d t^{*} \\
H(T, V(0), A, g, r, \delta, \sigma) \equiv \int_{0}^{T} e^{-r t} f(t ; V(0), A, g, r, \delta, \sigma) d t
\end{gathered}
$$

and

$$
I(T, V(0), A, g, r, \delta, \sigma) \equiv \int_{0}^{T} e^{-(r-g)} f\left(t^{*} ; V(0), A, g, r, \delta, \sigma\right) d t^{*}
$$

Closed form solutions for these expressions are derived in Ju (2001). These expressions are reproduced in section $A .1$ of the Appendix.

Following Leland and Toft (1996) and Ju (2001), the value of the debt at time zero is the sum of a contribution from the coupon, a contribution from the payment to debtholders if bankruptcy occurs, and the repayment of the face value at time $T$ if bankruptcy does not occur:

$$
\begin{aligned}
D_{i}(0)= & C_{i} \int_{0}^{T} e^{-r t^{*}}\left(1-G\left(t^{*}, V_{i}(0), F_{i} e^{-g T}, g, r, \delta, \sigma_{i}\right)\right) d t^{*} \\
& +\int_{0}^{T} e^{-r t^{*}}\left(1-\alpha_{B C}\right) F_{i} e^{-g\left(T-t^{*}\right)} f\left(t^{*}, V_{i}(0), F_{i} e^{-g T}, g, r, \delta, \sigma_{i}\right) d t^{*} \\
& +F_{i}\left(1-G\left(T, V_{i}(0), F_{i} e^{-g T}, g, r, \delta, \sigma_{i}\right)\right) e^{-r T}, \quad i \in\{N P, P\}
\end{aligned}
$$

or 


$$
\begin{aligned}
D_{i}(0)= & \frac{C_{i}}{r}\left(1-\left(1-G\left(T, V_{i}(0), F_{i} e^{-g T}, g, r, \delta, \sigma_{i}\right)\right) e^{-r T}-H\left(T, V_{i}(0), F_{i} e^{-g T}, g, r, \delta, \sigma_{i}\right)\right) \\
& +\left(1-\alpha_{B C}\right) F_{i} e^{-g T} I\left(T, V_{i}(0), F_{i} e^{-g T}, g, r, \delta, \sigma_{i}\right) \\
& +F_{i}\left(1-G\left(T, V_{i}(0), F_{i} e^{-g T}, g, r, \delta, \sigma_{i}\right)\right) e^{-r T}, \quad i \in\{N P, P\}
\end{aligned}
$$

Another modeling decision involves the question of whether the firm should refinance maturing debt. Ju (2001) presents two alternative models: The first is a "static" model, in which the firm does not refinance debt, and becomes an all-equity firm subsequent to the time the debt matures. The second is a "dynamic" model in which new debt is reissued at the time of maturity. Since the dynamic framework seems a priori more appealing, and in fact Ju shows that the refinancing assumption can affect corporate financing decisions ex ante, we analyze stockholder/manager conflict under the dynamic model. Nonetheless, it is convenient to present the solution of the dynamic model in terms of that for the static model that we develop now.

In the static model, when the firm is forced into bankruptcy at time $t^{*}$, the bankruptcy costs are $\alpha_{B C} V\left(t^{*}\right)$. Hence, at time zero the value of the bankruptcy costs are

$$
B C_{i}(0)=\int_{0}^{T} \alpha_{B C} F_{i} e^{g\left(t^{*}-T\right)} e^{-r t^{*}} f\left(t^{*} ; V_{i}(0), F_{i} e^{-g T}, g, r, \delta, \sigma_{i}\right) d t^{*}, \quad i \in\{N P, P\}
$$

or

$$
B C_{i}(0)=\alpha_{B C} F_{i} e^{-g T} I\left(T, V_{i}(0), F_{i} e^{-g T}, g, r, \delta, \sigma_{i}\right), \quad i \in\{N P, P\}
$$

The tax benefits of debt accrue to the firm as long as it has not gone bankrupt. Consequently, the tax benefits of debt in the static model can be computed by

$$
T B_{i}(0)=\int_{0}^{T} \tau C_{i} e^{-r t^{*}}\left(1-G\left(t^{*}, V_{i}(0), F_{i} e^{-g T}, g, r, \delta, \sigma_{i}\right)\right) d t^{*}, \quad i \in\{N P, P\}
$$

or 


$$
\begin{gathered}
T B_{i}(0)=\frac{\tau C_{i}}{r}\left(1-\left(1-G\left(T, V_{i}(0), F_{i} e^{-g T}, g, r, \delta, \sigma_{i}\right)\right) e^{-r T}-H\left(T, V_{i}(0), F_{i} e^{-g T}, g, r, \delta, \sigma_{i}\right)\right) \\
i \in\{N P, P\}
\end{gathered}
$$

The value of the equity is equal to the value of the assets plus the tax benefits of debt minus the bankruptcy costs minus the value of the debt:

$$
E_{i}(0)=V_{i}(0)+T B_{i}(0)-B C_{i}(0)-D_{i}(0), \quad i \in\{N P, P\}
$$

In order to compute the manager's time zero expectation of his utility at time $T_{u}$, let $V^{K}\left(T_{u}\right)$ be the value of the firm's assets at time $T_{u}$ that makes a share of stock worth $K$ at time $T_{u}$. Then the manager's time zero expectation of his utility at time $T_{u}$ is the sum of three components. The first component is a function of the probability density for the value of the firm's assets being at various levels above $V^{K}\left(T_{u}\right)$ at time $T_{u}$ without having touched the bankruptcy boundary between time zero and time $T_{u}$. The second component is a function of the probability density for the value of the firm's assets being at various levels below $V^{K}\left(T_{u}\right)$ at time $T_{u}$ without having touched the bankruptcy boundary between time zero and time $T_{u}$. The third component is the utility derived from his non-firm wealth if the bankruptcy boundary is hit. Let $g(V(0), V(T), T, A, g, \mu, \delta, \sigma)$ be the density function for starting at a value $V(0)>A$ and being at $V(T)>A e^{g T}$ at time $T>0$ without ever hitting the boundary $A e^{g t}$ in the interval $t \in[0, T]$ when the $V$ process follows geometric Brownian motion with drift $\mu-\delta$ and volatility $\sigma$. An explicit expression for $g(V(0), V(T), T, A, g, \mu, \delta, \sigma)$ is presented in Ju (2001). Then at time zero, the manager's expectation of his utility at time $T_{u}$ without and with the project are given by 


$$
\begin{aligned}
\text { Utility }_{i}(0)=\int_{V_{i}^{K}\left(T_{u}\right)}^{\infty} U\left\{N F W\left(T_{u}\right)\right. & \left.+\frac{N_{\text {Man }}+N_{\text {Calls }}}{N_{i}}\left[V_{i}\left(T_{u}\right)+T B_{i}\left(T_{u}\right)-B C_{i}\left(T_{u}\right)-D_{i}\left(T_{u}\right)\right]-N_{\text {Calls }} K\right\} \\
& \times g\left(V_{i}(0), V_{i}\left(T_{u}\right), T_{u}, F_{i} e^{-g T}, g, \mu, \delta, \sigma_{i}\right) d V_{i}\left(T_{u}\right)
\end{aligned}
$$

where $V_{i}^{K}\left(T_{u}\right)$ satisfies the following equation:

$$
K=\frac{V_{i}^{K}\left(T_{u}\right)+T B_{i}\left(T_{u}\right)-B C_{i}\left(T_{u}\right)-D_{i}\left(T_{u}\right)}{N_{i}}, \quad i \in\{N P, P\}
$$

Note that all terms in the numerator of the right hand side of equation (25) are a function of $V_{i}^{K}\left(T_{u}\right)$.

Next we extend the model to a more realistic dynamic setting. As in the static case, at time zero the firm has debt outstanding with $T$ years to maturity and the manager decides whether to accept a project. Now, however, if the firm has not gone bankrupt at the end of $T$ years, the firm issues new $T$ year debt at time $T$. The new debt pays a coupon of either $C_{N P} V_{N P}(T) / V_{N P}(0)$ or $C_{P} V_{P}(T) / V_{P}(0)$, respectively, depending upon whether the firm has foregone or accepted the project at time zero.

Similarly, as shown in Ju (2001), all other securities will be scaled by a factor of $V_{N P}(T) / V_{N P}(0)$ or $V_{P}(T) / V_{P}(0)$, because at time $T$ the firm is identical to itself at time zero except that it is $V(T) / V(0)$ as large. The process of issuing new $T$-year debt each time existing debt matures continues indefinitely until the firm goes bankrupt.

In this dynamic setting, the price of the debt is still given by equation (18). The firm value, however, will reflect the costs and benefits of the debt issued in the future until the firm goes bankrupt. In 
order to determine the total tax benefit and total bankruptcy cost of the current and potential future issues of debt, the following quantity will be useful:

$$
\phi_{i} \equiv e^{-r T} E^{Q}\left[\mathbf{1}_{\{\text {Firm does not go bankrupt over }[0, T]\}} \frac{V_{i}(T)}{V_{i}(0)}\right] \quad i \in\{N P, P\}
$$

The indicator function $\mathbf{1}_{\{\text {Firm does not go bankrupt over }[0, T]\}}$ is equal to one if the firm does not go bankrupt over the interval $[0, T]$ and zero otherwise. The expectation is taken over the risk-neutral $Q$ measure. Ju (2001) shows that $\phi$ is given by the following expression:

$$
\phi_{i}=e^{-\delta_{i} T}\left[N\left(d_{i}^{1}\right)-\left(\frac{F_{i} e^{-g T}}{V_{i}(0)}\right)^{2\left(1+\left(r-\delta-g-\sigma_{i}^{2} / 2\right) / \sigma_{i}^{2}\right)} N\left(d_{i}^{2}\right)\right], \quad i \in\{N P, P\}
$$

where

$$
d_{i}^{1}=\frac{-\log \left(F_{i} e^{-g T} / V_{i}(0)\right)+\left(r-\delta-g+\sigma_{i}^{2} / 2\right) T}{\sigma_{i} \sqrt{T}}, \quad i \in\{N P, P\}
$$

and

$$
d_{i}^{2}=\frac{\log \left(F_{i} e^{-g T} / V_{i}(0)\right)+\left(r-\delta-g+\sigma_{i}^{2} / 2\right) T}{\sigma_{i} \sqrt{T}}, \quad i \in\{N P, P\} .
$$

It is also shown in $\mathrm{Ju}(2001)$ that the total tax benefit of debt and the total bankruptcy costs are given by

$$
T B_{i}^{\text {Dynamic }}(0)=\frac{T B_{i}(0)}{1-\phi_{i}}, \quad i \in\{N P, P\}
$$

and

$$
B C_{i}^{\text {Dynamic }}(0)=\frac{B C_{i}(0)}{1-\phi_{i}}, \quad i \in\{N P, P\}
$$

Similarly to equation (23), the value of the equity is equal to the value of the assets plus the tax benefits of debt minus the bankruptcy costs minus the value of the debt:

$$
E_{i}^{\text {Dynamic }}(0)=V_{i}(0)+T B_{i}^{\text {Dynamic }}(0)-B C_{i}^{\text {Dynamic }}(0)-D_{i}(0), \quad i \in\{N P, P\}
$$


The value of the debt is the same in the static and the dynamic model.

\section{Calibrating the Model}

The total value of the firm's assets without the project is normalized to $\$ 100$ at time $T_{0}$. This value (plus the tax benefit of debt) is divided between debtholders, stockholders who own a total of 100 shares, and bankruptcy costs. We assume that the manager of the firm owns a 0.32 share of stock and a 10-year exchange traded European call option on an additional 0.38 share. ${ }^{4}$ The strike price for the call option is set equal to the time zero value of a share of equity of the firm without the project. For the basecase, the manager's non-firm wealth is assumed to equal the time-zero value of the shares that the manager owns without the project. Consistent with the literature, we assume the manager's risk aversion parameter $\gamma$ equals 2 (see pp. 258-260 of Ljungqvist and Sargent (2000) for a discussion of the interpretation of this value and other values of $\gamma$ used in the sensitivity analysis). We also assume that the value of the cash flows from operations of the project is sufficient to ensure that the total value of the firm's assets with the project equals $\$ 120$ at time $T_{0}$.

Given these assumptions, calibration of the model requires estimates of (1) the risk-free rate, $r$, (2) the effective tax rate, $\tau$, (3) the drift parameter for the total value of the firm, $\mu$, (4) the volatility of the total value of the firm with no project, $\sigma_{N P},(5)$ the level of dividends, DivRate, paid by the firm, (6) the face value of the debt with no project, $F_{N P}$, (7) the volatility of the total value of the firm with the project, $\sigma_{P}$, (8) the debtholder bankruptcy recovery rate, $\left(1-\alpha_{B C}\right)$, and (9) the bankruptcy boundary's exponential growth rate, $g$. Where possible, we estimate these parameters using data from the end of January 2001, so that the model's implications are realistic and reasonably current.

\footnotetext{
${ }^{4}$ The manager's stock and option holdings represent the median values for managers at 1,405 firms for which sufficient data to estimate these figures are available for 1999 on the ExecuComp database.
} 
As our estimate of the risk-free rate, we use the rate on 10-year Treasury bonds as of January 30 , 2001 as reported in the February 7, 2001 edition of Standard \& Poor's The Outlook. This rate equals 5.22 percent.

We estimate the tax rate used to calculate the tax shields from the debt using data on estimated marginal tax rates (before interest expense) provided by John Graham, who constructed these estimates using the approach described in Graham (1996). In particular, for the base case, we assume that the tax rate equals the median marginal tax rate of 34 percent for the 5,519 firms for which 1999 estimates are available.

We set the drift parameter of the firm, $\mu$, equal to 5 percent. This value is consistent with an expected long-term inflation rate of 2.5 percent and 2.5 percent real growth. The 2.5 percent long-term inflation rate is consistent with five-year estimates published by WEFA (formerly Wharton Econometric Forecasting Associates) for the Consumer Price Index in its US Outlook report for December 2000.

To estimate the volatility of the total value of the firm's assets with no project, $\sigma_{N P}$, we examine the sample of 1,043 firms for which the necessary data are available on COMPUSTAT for the entire 1980 to 1999 period. The median value of the annual standard deviation of the percentage change in firm value for the 1,043 firms, 0.2852 , provides a lower bound for our estimate of $\sigma_{N P}{ }^{5}$ This value is a lower bound because there is a survivorship bias in the sample. We use 0.32 as our estimate of the value of $\sigma_{N P}$ for the universe of firms.

We set the dividend rate, DivRate, equal to 1.5 percent in the base case. Because this rate is stated as a percentage of the unlevered value of the firm, we use a number that is on the lower end of the 1.50 to 2.0 percent dividend yield paid by public firms at the beginning of 2001 .

\footnotetext{
${ }^{5}$ This estimate is only an approximation, as it does not incorporate bankruptcy costs, which are not observable. It is relatively insensitive to the sample and period. Estimates of $\sigma_{\mathrm{NP}}$ range from 0.2513 to 0.3333 for different time periods (ten and 20 years) and samples (firms for which all data are available for the full 20 year period and for which data are only available for ten years).
} 
We base our choice of the face value of the debt at the firm with no project on the distribution of the ratio of the book value of debt to the book value of debt plus the market value of the equity for all 6,974 firms for which there are sufficient data to estimate this ratio on COMPUSTAT in 1999. This distribution is:

\begin{tabular}{rrr} 
Percentile & Equity/TC & Debt/TC \\
\hline & & \\
$0 \%$ & $0.00 \%$ & $100.00 \%$ \\
$10 \%$ & $25.10 \%$ & $74.90 \%$ \\
$20 \%$ & $41.40 \%$ & $58.60 \%$ \\
$30 \%$ & $54.00 \%$ & $46.00 \%$ \\
$40 \%$ & $66.50 \%$ & $33.50 \%$ \\
$50 \%$ & $78.10 \%$ & $21.90 \%$ \\
$60 \%$ & $88.50 \%$ & $11.50 \%$ \\
$70 \%$ & $95.20 \%$ & $4.80 \%$ \\
$80 \%$ & $98.80 \%$ & $1.20 \%$ \\
$90 \%$ & $99.90 \%$ & $0.10 \%$ \\
$100 \%$ & $100.00 \%$ & $0.00 \%$
\end{tabular}

This distribution illustrates the wide variation in capital structures that is observed in public U.S. firms. We select the face value of the debt with no project, $F_{N P}=\$ 22.47$, so that its market value equals the median value of this distribution (21.90 percent) at time 0 . Because of the importance of this parameter, we also present results for alternative capital structures.

The volatility of the value of the firm's assets with the project, $\sigma_{P}$, is computed based on the volatility of the value of the firm's assets with no project $(0.32)$, the volatility of the value of the assets of the project (set equal to the volatility of the value of the firm's assets with no project), a correlation between total firm (with no project) and project asset value volatilities of 0.5 , and a project with a value equal to 20 percent of the value of the firm, using the standard portfolio formula. This yields a value of 0.29695 for the base case volatility of the firm's assets with the project. $\sigma_{P}$ ranges from 0.2667 to 0.5583 in the base-case sensitivity analyses below. This range corresponds to that used by Parrino and Weisbach (1999) where the volatility of the project varies from zero to approximately eight times the volatility of the firm without the project. 
The debtholder bankruptcy recovery rate and the exponential growth rate for the bankruptcy boundary are selected to yield an expected recovery rate of 45 percent and a spread over the 10-year Treasury bond rate for the firm's debt equal to 1.90 percent. The 45 percent recovery rate is broadly consistent with recovery rates published by Hamilton, Gupton, and Berhault (2001). For the 1981 to 2000 period, Hamilton, Gupton, and Berhault estimate the mean default recovery rates for senior secured bonds, senior unsecured bonds, and subordinated bonds of all ratings to equal 53.9 percent, 47.4 percent, and 32.3 percent, respectively. The 1.90 percent spread over the Treasury bond rate equals the spread for 10-year A-rated corporate debt as of January 30, 2001, as reported in the February 7, 2001 edition of Standard \& Poor's The Outlook. The bankruptcy recovery and bankruptcy boundary growth rates for our base case equal $0.5194\left(\alpha_{\mathrm{BC}}=0.4806\right)$ and 5.19 percent, respectively.

Panel A of Table I summarizes our parameter choices. These choices are used to derive the set of parameters that are presented in Panel B of Table I.

\section{Implications of the Models for Investment Decisions}

This section discusses the implications of our models for investment decisions at a hypothetical "typical firm." We first summarize the implications of the models using the base case parameters presented in Panel A of Table I. We then perform sensitivity analyses where we consider how the results change with alternative parameters choices.

\section{A. Base-Case Results}

Tables II through IV present statistics describing the impact of a zero NPV project on variables in the models discussed above. ${ }^{6}$ In each case, the project is a zero NPV project that increases the value of the firm's assets by 20 percent. $^{7}$ The present values of tax shields and bankruptcy costs change in each

\footnotetext{
${ }^{6}$ Throughout the paper we define a project's NPV as the change in the present value of a firm's assets, minus the project's cost. Note that this definition excludes financing effects in that it does not directly account for the effect of a project on the firm's tax shields or bankruptcy costs. These effects are accounted for separately in Tables II through IV.

${ }^{7}$ This size assumption (among others) is relaxed below when we perform sensitivity analyses in Section III.B.
} 
case because the project alters the firm's capital structure and business risk, thereby affecting the size of the debt tax shield, conditional on the firm being able to utilize it, as well as the probability distribution of bankruptcy, and therefore the ability of the firm to utilize the debt tax shield.

Table II summarizes the most important statistics for the case using the financing rule where the market debt/total capital ratio for the project financing equals the pre-project market debt/total capital ratio of the firm. We focus on this case because we believe it is the most plausible of the financing rules we consider. For comparison purposes, we also present results for similar firm, project, and manager characteristics under the other two financing rules in Tables III and IV. The results in each table are based on the parameter values listed in Table I, except that the volatility of the value of the assets of the firm with the project is varied from 26.67 percent to 55.83 percent.

The first two rows in Tables II through IV report the volatility of the value of the firm's assets both without and with the project. Because of the different financing assumptions, the leverage ratios with the project vary substantially across Tables II through IV, despite the fact that, in all scenarios, in each table, the firm's debt to total capital ratio without the project is set equal to 21.90 percent. In Table II, using the financing rule requiring the new project to be financed with debt and equity in the same proportion as that at the firm without the project, post-project leverage is slightly higher than pre-project leverage with projects that produce low firm volatilities, and declines moderately as projects produce higher firm volatilities (Row 4). With low-risk projects (i.e., those that lower the volatility of the firm's asset value), existing debt becomes less risky and hence more valuable (Row 11). Meanwhile, the value of debt tax shields increases due to a lower probability of default (Row 25), causing the value of the existing equity to also increase (Row 19), despite the wealth transfer to debtholders. The net result of these changes is that the value of the existing debt increases slightly more, in dollar terms, than the value of the equity, resulting in an increase in leverage. As project risk increases (i.e., as the volatility of the firm with the project increases), both debt and equity decrease in value due to increasing bankruptcy costs 
and a decreasing tax shield value. The net effect of these changes is to cause the value of the debt to decline more rapidly than the value of the equity.

Table III illustrates the case where the project is financed so that existing debtholders do not suffer any gain or loss on the value of their claims. In this model, leverage ratios change dramatically depending on the riskiness of the project that is adopted. For example, the leverage of the firm increases to 28.71 percent with a project that reduces firm volatility to 26.67 percent, while leverage decreases to only 4.89 percent with a project that increases firm volatility to 55.83 percent (Row 4 ). The reason for this strong negative relation between project risk and leverage is that existing debt becomes more risky as the volatility of the firm almost doubles from 32.00 percent to 55.83 percent. In order to offset this increase in risk and make the existing debtholders indifferent, the quantity of debt outstanding must be reduced (implicitly assuming that the debt is repurchased from some debtholders at a fair price). Finally, the results in Table IV are for the financing scenario in which market debt/equity ratio is held constant at the pre-project ratio of 21.90 percent.

\section{A.1. Changes in the Values of Equity and Debt Claims}

As suggested by Fama and Miller (1972), Jensen and Meckling (1976), and Myers (1977), undertaking a zero NPV project that causes firm volatility to change will in general transfer wealth between stockholders and debtholders. In the absence of other factors, a zero NPV project that increases firm risk transfers wealth from debtholders to stockholders, and a zero NPV project that decreases firm risk transfers wealth from stockholders to debtholders.

However, there are other factors that complicate this relation in a levered firm. In particular, changing firm risk affects the expected value of both interest tax shields and bankruptcy costs. To illustrate this point, suppose that a firm adopts a project that decreases the firm's overall risk. This will increase the probability that the firm will be able to utilize the tax shields in any period, increasing the value of the tax shields. In addition, expected bankruptcy costs decrease because the probability of default is reduced. These effects are, of course, reversed if the firm adopts a project that increases firm 
risk. The wealth transfers between claimholders, as well as the changes in the values of the tax shields and bankruptcy costs, determine the net changes in the values of existing equity and debt when a project is financed with fairly priced debt.

Tables II through IV illustrate how the overall effect of adopting a project that alters firm risk on the value of stockholder and debtholder claims can be decomposed to compare the relative sizes of the various factors that affect these values. The wealth transfers are most easily seen in Rows 14 and 22, which indicate changes in the values of original debt and equity, when taxes and bankruptcy costs are zero. In all cases, except the one in which original debtholders are made whole and wealth transfers are ruled out by construction (Table III), debt values increase (decrease) and equity values decrease (increase) when a low-risk (high-risk) project is adopted. Note that these are pure wealth transfers, as the changes in the values of the equity and debt claims always exactly offset each other.

Rows 25 and 28 in Tables II through IV present the changes in values of the tax shields and bankruptcy costs under the alternative financing assumptions when the tax rate and bankruptcy costs are not set equal to zero. The figures in these rows indicate that tax shields decrease with project risk and that bankruptcy costs increase with project risk. These changes, along with the wealth transfer effect, combine to determine the changes in the value of original debt and equity, indicated in Rows 11 and 19 of Tables II through IV.

Comparison of the relative magnitudes of these effects provides useful insights. The effect of changing firm risk on the value of tax shields is large relative to the wealth transfer effect for the typical firm. For example, given the assumptions underlying the analysis in Table II, a low risk project that decreases firm volatility to 26.67 percent transfers $\$ 0.40$ from stockholders to debtholders (see Table II, Rows 14 and 22). The argument is often made (e.g., Myers (1977)) that this risk shifting is one reason stockholders might avoid low risk projects. However, undertaking this project adds $\$ 1.66$ to the value of the tax shields (Row 25), more than four times as much value as is transferred from the stockholder to the debtholders with the same project. Most of this value accrues to the stockholders. When the change in 
bankruptcy costs is taken into account (-\$0.79 in Row 28), the net gain to stockholders is $\$ 1.14$ from this project. $^{8}$ Note that there is no conflict between stockholders and debtholders from this zero NPV project; the debtholders gain $\$ 1.31$ as well, because the low-risk project decreases the default risk of their claims. ${ }^{9}$

The value of equity claims actually decreases when a high-risk project is adopted, despite the wealth transfer to stockholders. For example, Table II shows that, while the adoption of a project that produces a firm volatility of 55.83 percent results in a wealth transfer of $\$ 2.31$ from debtholders to stockholders, the reduction in the value of debt tax shields, $-\$ 0.73$ in Row 25 , and increased bankruptcy costs, $\$ 5.52$ in Row 28, more than offset the impact of the wealth transfer on share values, even after accounting for the change in the value of the debtholder claims. The net result is a decrease in stockholder wealth of $\$ 0.82$ (Row 19).

These estimates suggest that, at least for firms with moderate leverage, the usual intuition derived from agency theory is reversed once tax effects and bankruptcy costs are taken into account. In contrast to the intuition from Jensen and Meckling (1976) and Myers (1977), it appears that there is little disagreement between debtholders and stockholders over project choice. All other things equal, both debtholders and stockholders prefer safe projects to risky ones; wealth is in fact transferred, but the wealth transfer is more than offset by the changes in taxes and bankruptcy costs. Note that this argument does not rely on managerial risk aversion, which will exacerbate the tax and bankruptcy cost effects.

Our perspective on tax and bankruptcy effects differs from that typically found in corporate finance textbooks. Taxes and bankruptcy costs are usually discussed in corporate finance courses in the context of the "Tradeoff" theory of capital structure, in which, ex ante, firm managers trade-off the relative benefits and costs in choosing a capital structure. The results in Tables II through IV suggest that once a capital structure is chosen, taxes and bankruptcy costs have values that are affected by the

\footnotetext{
${ }^{8}$ The reason changes in bankruptcy costs accrue to the stockholders in addition to the debtholders is that, in our dynamic model, stockholders bear the incremental changes in the cost of capital when they issue debt in the future. ${ }^{9}$ Note that the total change in the value of debt plus equity equals the change in the value of the tax shields minus the change in bankruptcy costs in Tables II through IV. For example, in the first column of Table II, the change in the value of the debt $(\$ 1.31)$ plus equity $(\$ 1.14)$ equals $\$ 2.45$. The change in the value of the tax shields $(\$ 1.66)$ minus the change in bankruptcy costs $(-\$ 0.79)$ also equals $\$ 2.45$.
} 
investment decisions made by managers. Therefore, ex post, once the capital structure is chosen, tax and bankruptcy costs create investment distortions that have not been emphasized in the literature. Incorporating these effects into a theory of optimal capital structure would be a fruitful topic for future research.

\section{A.2. Changes in the Manager's Utility}

We evaluate the impact of the project from the manager's perspective in the bottom panel of Tables II through IV. In these panels, we characterize the distortion in investment decisions by estimating the project cost necessary to make the manager indifferent as to whether the project is accepted. To do this, we solve for the project cost that sets the change in the manager's utility equal to zero. This cost will generally be different from the cost at which the project has a zero NPV; for projects that reduce firm volatility, this cost will typically be higher than the zero NPV cost, and for projects that increase firm volatility, it will typically be lower. Each of these cost estimates implies an "indifference NPV," which is the NPV at which the manager is indifferent between accepting and rejecting a project with a specified volatility.

To evaluate the importance of these distortions, it is useful to express them in terms of incremental rates of return. Since our model is based on a value process that does not explicitly model cash flows, we must first calculate the implied level of cash flows from operations for the project. The implied initial cash flow from operations for the project is computed as $\mathrm{CF}=\Delta \mathrm{V}(\mathrm{WACC}-\mu)$ where $\Delta \mathrm{V}$ is the change in the value of the firm's assets if the project is adopted, WACC is the weighted-average cost of capital of the firm at time zero, and $\mu$ is the drift parameter of 0.05 . The WACC is computed using the leverage of the firm with the project, a tax rate of 34.0 percent (estimated from 1999 simulated tax rates provided by John Graham), a cost of debt estimate based on the leverage of the firm, and a cost of equity estimate based on the CAPM. The cost of debt is obtained by first estimating a probable credit rating for the firm's debt based on its capital structure using data from Moody's Financial Ratio Medians for Global Investment Grade Corporates, January 2001. This credit rating is then used to compute the 
cost of debt by adding the spread over the risk-free rate, for debt with the probable credit rating, reported for January 30, 2001 in the February 7, 2001 issue of Standard and Poor's The Outlook. The cost of equity is estimated from the CAPM using an asset beta of 0.76 that is levered to reflect the leverage of the firm at time zero, a risk-free rate of 5.22 percent and a market risk premium of 7.40 percent. This calculation models the cash flows from operations of the project as a growing perpetuity with a growth rate equal to the drift parameter, $\mu$, from our model.

We next assume that the cost of the project equals the cost that makes the manager indifferent and solve for the cost of equity implied by our estimate of the level of the initial operating cash flows from the project, again modeling the cash flows from operations for the project as a growing perpetuity with a growth rate equal to the drift parameter from our model. Finally, we compute the incremental cost of equity where the manager is indifferent as the difference between the cost of equity estimated this way and the cost of equity used to estimate the implied initial cash flow from operations for the project (described in the previous paragraph). This incremental cost of equity has a natural interpretation as the extra cost, in rate of return terms, of the net agency costs between stockholders, debtholders, and managers.

These effects are illustrated in the bottom panels of Tables II through IV. Row 31 in these tables indicates the project cost for which the managers are indifferent towards taking the project. The manager's "indifference NPV," which equals the value of the project, $\$ 20$, minus the "indifference cost" from Row 31, is presented in Row 32. This is converted to an "incremental cost of equity" in Row 38.

As can be seen in each table, both the indifference NPV and the incremental cost of equity are increasing in project risk. This relation is determined by a combination of factors. Two factors, the wealth transfers between debtholders and stockholders and the impact of risk on the value of stock options, work to make riskier projects more desirable through their impact on the values of the manager's 
shares and options. ${ }^{10}$ Working against these factors is the manager's risk aversion, and the changes in the value of debt tax shields, and bankruptcy costs.

To facilitate understanding of these various effects, we decompose the incremental rates of return and indifference NPVs by factor in Rows 33-37 and Rows 39-43 of Tables II through IV. In Rows 36 and 42, we present the incremental cost of equity and indifference NPV for the case of a risk-neutral manager without taxes or bankruptcy costs. Since these results are computed for cases where managers are not risk averse and there are no taxes or bankruptcy costs, we would expect that managers prefer more risky projects. Not surprisingly, in each table, the required NPV and the incremental rate of return decrease with project risk. Rows 35 and 41 of these tables present the same variables, except for a riskaverse manager. Once risk aversion is added to the model, the relations between the indifference NPV and incremental rate of return and project risk change sign and increase in project risk, suggesting that with a moderately risk-averse manager $(\gamma=2)$, risk aversion is a more important factor than wealth transfers between stockholders and debtholders. ${ }^{11}$

We add tax effects and bankruptcy effects individually in Rows 33, 34, 39 and 40. We do so by considering the cases where the tax rate equals zero, and where the bankruptcy cost parameter equals zero separately. Not surprisingly, in each of these two cases, the relation between project risk and indifference NPVs or incremental rates of return becomes more steeply-sloped than the case with no taxes or bankruptcy costs (Rows 35 and 41), but less steep than the case including all effects (Rows 32 and 38).

\section{B. Stockholder/Manager Conflicts and Variation in Underlying Parameters}

The base case analysis documents how the values of equity and debt change when a firm adopts a project that changes firm-wide risk, and illustrates the extent to which stockholder/manager conflicts can

\footnotetext{
${ }^{10}$ Carpenter (2000) emphasizes that stock options do not necessarily increase in value with firm risk when held by an undiversified executive. However, given the parameters used here, the "option" effect dominates the risk effect, so that the options are increasing in value to the manager when firm risk increases.

${ }^{11}$ Stock options complicate this analysis somewhat. When we replicate these numbers for the model without stock options as seen in Rows 37 and 43 (or with stock options replaced by a comparable amount of common stock in the manager's portfolio) the relations illustrated in lines 36 and 42 become less pronounced, indicating that the option effect reinforces the wealth transfer effect rather than the risk aversion effect.
} 
affect the decision to accept or reject potential projects. The results presented to this point are for a model that is calibrated to resemble a typical large, publicly traded firm. This subsection varies a number of the underlying model parameters and examines the sensitivity of the estimates of the magnitude of the impact of stockholder/manager conflicts on investment decisions to our choice of model parameters.

\section{B.1. Variation in Leverage}

The magnitude of the impact of project risk on the indifference NPV is illustrated in Figures 1a and $1 \mathrm{~b}$ for firms with differing initial degrees of leverage. Figure 1a illustrates the indifference NPV for different initial leverage ratios, while Figure $1 \mathrm{~b}$ converts these NPV values into incremental rates of return. ${ }^{12}$ The lines for 0.01 percent leverage and 21.9 percent leverage (the base case leverage used in producing Tables II through IV) slope upward, indicating that as projects get riskier, they become less desirable to managers. Comparing these two lines, the line for 21.9 percent leverage slopes upward more steeply than the line for 0.01 percent leverage. In contrast, when leverage ratios increase to higher levels (e.g., 50 percent and 75 percent) the relations between indifference NPV or incremental rate of return and volatility become negative, with the more levered firm having the more negatively sloped relation.

To understand the patterns of the relations illustrated in Figure 1, it is important to consider the various means through which leverage can affect the impact of risk changes on a manager's utility: First, the magnitude of wealth transfers between stockholders and debtholders increases with leverage. This leads managers to prefer risky projects, since they hold shares and options on the firm's shares. The remaining factors work in the opposite direction as leverage increases, causing managers of more levered firms to prefer less risky projects. Increasing risk through the adoption of a risky project increases expected bankruptcy costs more when a firm has greater leverage. In addition, risk-induced changes in the value of tax shields are sensitive to leverage: Since the value of debt tax shields, conditional on the firm being able to use them, increases with leverage, the impact of a change in risk on the value of debt

\footnotetext{
${ }^{12}$ This figure and the figures discussed below are based on the model in which new projects are financed with debt and equity in proportion to the debt and equity in the firm's existing capital structure. Comparable figures using the other two models lead to similar results.
} 
tax shields is magnified when a firm has more leverage. Finally, Modigliani and Miller's Proposition 2 implies that leverage causes stockholders to bear a disproportionate share of a given increase in firm risk. Consequently, risk aversion will lead managers of more levered firms to be less inclined to adopt risky projects than similarly risk-averse managers of firms with less debt.

Figure 1 indicates that the various factors affecting stock and debt prices have a nonlinear relation with leverage. At low levels of leverage, the fact that higher leverage (e.g., debt to total capital of 21.9 vs. 0.01 percent) increases the slopes of the lines in Figure 1 suggests that the risk aversion, tax, and bankruptcy cost effects, combined, are larger than the wealth transfer effect. However, as firms become highly levered, the wealth transfer effect dominates, so that managers of highly levered firms have incentives to invest in projects that increase firm risk. ${ }^{13}$ Results not reported in Figure 1 suggest that the slope of the lines illustrated in Figure 1 become negative when leverage increases above approximately 35 percent.

\section{B.2. Variation in the Manager's Risk Aversion}

The choice of the risk aversion coefficient $(\gamma)$ is an important one in an analysis such as this. Managerial risk aversion is fundamentally unobservable, yet one of the most important underlying variables in all of economics. Therefore, it is not surprising that the appropriate coefficient of risk aversion has been a subject of much debate. Given our goal of examining the implications of managerial risk-aversion on project choice, our approach is to first examine the implications of our model using a reasonable parameter value that has been suggested by others and to then examine the sensitivity of the results to this parameter value. In our analysis to this point we have used a value of 2 for $\gamma$, based on the discussion in Ljungqvist and Sargent (2000) (pp. 258-260). In this subsection we evaluate the sensitivity of the estimates from our model to this choice.

\footnotetext{
${ }^{13}$ Andrade and Kaplan (1998) find no evidence of excessive risk-taking in their sample of firms that have highlyleveraged transactions.
} 
In Figures $2 \mathrm{a}$ and $2 \mathrm{~b}$ we present graphs of the indifference NPV and the incremental cost of equity for our base-case firm with risk aversion parameter estimates of 0 (the risk neutral case), 2, and 5. The graphs in Figures $2 \mathrm{a}$ and $2 \mathrm{~b}$ clearly indicate that the distortion due to stockholder/manager conflicts is extremely sensitive to $\gamma$. The risk-neutral line is relatively flat at zero in both graphs. While slightly positive for projects that produce firm volatilities less than about 30 percent, the risk neutral line is below zero for all other projects, indicating that a risk neutral manager likes zero net present value projects that slightly reduce firm volatility, but dislikes those that reduce it substantially. As risk aversion increases, so does the steepness of both curves. Not surprisingly, as the manager becomes more risk averse, riskreducing projects become more attractive and risk-increasing projects become less attractive.

\section{B.3. Variation in the Manager's Non-Firm Wealth}

Our base-case scenario assumes that the manager's non-firm wealth equals the value of his stock holdings (excluding options). Since we do not know of reliable data on the outside wealth of corporate managers, relative to the value of the shares they hold, this seems to us to be a reasonable starting point. However, given the uncertainty about what a reasonable value for the outside wealth of a typical manager is, as well as the substantial cross-sectional variation in non-firm wealth that undoubtedly exists, it is important to understand the impact of this assumption on the distortion in investment behavior due to stockholder/manager conflicts. Therefore, we present in Figures $3 \mathrm{a}$ and $3 \mathrm{~b}$ estimates of the indifference NPV and incremental rates of return for three values of outside wealth, relative to the value of the manager's stockholdings: 10 percent, 50 percent, and 90 percent.

As can be seen in Figures 3a and 3b, the level of outside wealth has a dramatic effect on investment incentives. When the manager has a high level of non-firm wealth, the line is almost flat. The high level of non-firm wealth in this case reduces the impact of the manager's investment decision on his total wealth, thereby reducing the impact of the investment decision on his utility. In contrast, when the manager has a low level of non-firm wealth, the lines in Figure 3 slopes steeply upwards. When non-firm wealth is low, the firm's stock represents a high proportion of the manager's total wealth, and the 
manager is very reluctant to undertake a project that makes the stock more volatile. Therefore, the manager will only accept risky projects that have very large NPVs. In contrast, when the manager has a lot of non-firm wealth, he is relatively diversified, and is more concerned about value than risk when making the firm's investment decisions.

\section{B.4. Variation in Project Size}

In the base-case analysis we assume that the value of the assets of the project equals 20 percent of the value of the assets of the firm without the project. We vary this value from 10 percent to 50 percent along with the cost of the project (from $\$ 10$ to $\$ 50$ ) in Figures $4 \mathrm{a}$ and $4 \mathrm{~b}$. These figures clearly indicate that both the indifference NPV and the incremental cost of equity slope upward more steeply with larger projects than with smaller ones. While these results might appear to be counter-intuitive since the rate of return on the projects is similar, the greater impact of the larger projects on the indifference NPV reflects the greater impact that these projects have on the volatility of the firm. For example, while the volatility of the assets of the firm with a project 20 percent the size of the firm ranges from 26.67 percent to 55.83 percent, the corresponding range is from 21.33 percent to 87.64 percent for a project 50 percent the size of the firm. These findings indicate that a larger high-risk project has a disproportionately large impact on the distortion of the investment decision when the manager is risk-averse.

\section{B.5. Variation in Debt Maturity}

Our base case model assumes that the firm is financed with ten-year debt. We select a debt maturity of ten years because the duration of this debt is similar to the weighted-average duration of debt issued by large corporations. However, the data suggest that there is substantial cross-sectional variation in debt maturity (see Barclay and Smith (1995)). Therefore, we evaluate the effect of different maturities on the stockholder/manager conflicts considered in this paper.

Figures $5 \mathrm{a}$ and $5 \mathrm{~b}$ present the results of our model for debt having five-, ten-, and 15-year maturities. The results in Figures $5 \mathrm{a}$ and $5 \mathrm{~b}$ indicate that the longer the duration of the debt, the smaller 
the distortions in investment. The intuition for these results follows from the fact that the tax shield effect, the bankruptcy cost effect, and the risk aversion effect are likely to be relatively independent of debt duration. These effects are mainly driven by the size of the debt. However, duration does affect the magnitude of wealth transfer from either risky or safe projects. The magnitude of these transfers is positively related to the maturity of the debt. Wealth transfers mitigate the effects of a change in firm volatility to the manager and on the value of debt tax shields and bankruptcy costs to a greater extent with longer-term debt than with shorter-term debt. As a result, the lines in Figures 5a and 5b are flatter for long-term debt.

\section{B.6. The Structure of Stock Options}

Much discussion in the compensation and corporate finance literature concerns the incentives that stock options provide and how option grants can best be structured. (See, for example, Hall and Murphy (2000)). This analysis is typically presented in the context of formal models of stylized firms. In contrast, our model provides a way to examine the effect of stock options on management incentives to take risks in the context of a model calibrated to realistically reflect a number of factors not usually considered in these models.

We first consider the differences between options and stock ownership. Firms typically grant their employees call options as part of their compensation packages. They do so by choice; in fact some firms choose to grant restricted shares instead of options. Unlike options, restricted shares force managers to bear both upside and downside risk.

Recall that, in our base case, we set the percentage of the firm's shares on which the manager holds options equal to 0.38 percent and the percentage of shares the manager owns equal to 0.32 percent. ${ }^{14}$ To consider the effects of option and stock holdings on risk-taking, in Figures $6 \mathrm{a}$ and $6 \mathrm{~b}$ we

\footnotetext{
${ }^{14}$ Note that the stock in the model is effectively restricted stock since management is not permitted to sell it or to hedge its risk. Recently, management has become increasingly able to hedge their positions in their personal position in their company's stock using derivatives (see Bettis, Bizjak, and Lemmon (2001)). Modeling the costs and benefits of such hedging behavior explicitly is likely to become more important as more managers hedge their portfolios in this manner.
} 
compare the base case to cases where the same overall fractional ownership, 0.70 percent, is represented entirely by option holdings or by stock holdings.

Figures $6 \mathrm{a}$ and $6 \mathrm{~b}$ tell a fairly straightforward story. The plot for the case where the manager has all options slopes downward. The base case plot, as before, slopes upward, and the plot for the case where the manager holds only stock slopes upward more steeply than for the base case. These results reflect the fact that the value of the options increases with risk. This increase in option value more than offsets the tax shield and bankruptcy cost effects and managerial risk aversion with high-risk projects when the manager holds only options. In contrast, when the manager holds only stock, the indifference NPVs and incremental rates of return increase with the risk of the project. These results suggest that one advantage of options over restricted stock is that they provide better risk-taking incentives.

Another question we examine, considered in detail in Hall and Murphy (2000), is how firms should set the exercise price of the option. The exercise price is typically set equal to the stock price at the time of the option award. Figures $7 \mathrm{a}$ and $7 \mathrm{~b}$ present estimates from our model which allow us to compare three cases: the base case in which options held by the manager have an exercise price equal to the fair market value of the shares of the firm without the project, as well as cases in which the option exercise prices equal 50 percent and 150 percent of stock value.

Figure 7 shows that setting the exercise price equal to 100 percent and 150 percent of the stock value leads to virtually identical risk-taking behavior. However, when options are structured with the exercise price equal to 50 percent of the market price, distortions from risk-taking are substantially larger. This result makes intuitive sense, since in-the-money options are more like stock than at-the-money or out-of-the-money options. With in-the-money options, management is more averse to downside movements in stock value, and thus requires a higher rate of return to undertake risky projects.

\section{Implications of the Models for a Sample of Public Firms}

We also use our model to estimate the magnitude of potential distortions in investment decisions at 15 public firms, five each from the paper and allied products, beer and wine, and wholesale distribution 
industries. These estimates provide additional insights on the willingness of risk-averse managers at levered firms to invest in projects with various levels of risk.

The firms selected within each industry exhibit considerable variation in leverage, the duration of their debt, their marginal tax rate, and/or the stock and options held by the CEO. Across the 15 firms, leverage varies from 6.24 percent (Kimberly-Clark) to 63.44 percent (Valley National), The duration of outstanding debt varies from 2 years (Valley National) to 23 years (Mead), the marginal tax rate varies from 0.121 (Stewart \& Stevenson) to 0.352 (Speizman Industries), stock ownership varies from 0.02 percent (Boise Cascade) to 75.90 percent (Valley National) of total shares, and option holdings vary from 0.29 percent (Kimberly-Clark) to 10.66 percent (Golden State Vintners) of total shares. The actual values for each of these variables are used in estimating the investment distortions for each firm.

For all firms, we assume that the manager has a risk aversion parameter of 2, that the manager's non-firm wealth equals the value of the stock that he owns, and that the drift of the firm and project asset values is 5 percent. The debtholder bankruptcy recovery rate and the exponential growth rate for the bankruptcy boundary are selected to yield an expected recovery rate of 45 percent in all cases. The volatility of each firm's asset value is selected so that the spread between the cost of debt and risk free rate is consistent with the firm's credit risk. As with our base case estimates, the project's asset value is assumed to equal 20 percent of the firm's asset value.

Figure 8 summarizes the results from these estimates. The most striking feature of the plots in Figure 8 is that, with the exception of Mead (in Figure 8a), the indifference NPV values are positive for projects with volatilities more than 1.75 times the respective firm volatilities. ${ }^{15}$ For comparison, the corresponding ratio for the typical firm with 21.90 percent leverage in Figure 1a is 2.10 times firm volatility. This evidence suggests that managers can have relatively little incentive to invest in highly risky projects even when they receive relatively large amounts of option-based compensation. The plot

\footnotetext{
${ }^{15}$ Note that, instead of the post-project volatility reported in previous figures, we report the ratio of the volatility of the project asset value to the volatility of the firm asset on the horizontal axis in each plot in Figure 8. We do this because the asset volatilities, without the project, differ across firms. This ratio facilitates a more meaningful comparison of the results.
} 
for Mead slopes downward due to the long duration of its debt (23 years) and its relatively high leverage (30.75 percent).

\section{Conclusions}

Since Jensen and Meckling (1976) and Myers (1977), it has often been argued that the managers of a levered firm, who usually have a stake in the firm's equity but not the firm's debt, have incentives to accept projects that are too risky. In particular, they will accept some relatively risky, negative NPV projects, and reject some relatively safe, positive NPV projects. This discussion generally ignores or downplays the importance of managerial risk aversion, which is an important source of conflict between stockholders and managers and, consequently, a central consideration in the design of incentive systems (Prendergast (1999)). In addition, risk changes can have important implications for the magnitude of other components of firm value, such as expected bankruptcy costs and tax shields. We know relatively little about the various mechanisms through which changes in a firm's risk affect a manager's utility, and subsequently, the extent to which these changes distort investment decisions.

This paper assesses the quantitative importance of the distortion in investment decisions arising from a number of factors, with the goal of assessing the relative importance of these factors. It presents a dynamic model in which a manager of a levered firm, who owns a fraction of the equity and holds options on this equity, decides whether to undertake a risky project, and does so based on his own utility function. The model, calibrated using current market data and typical firm and manager characteristics, uses contingent-claims methods to estimate the values of the firm's equity, debt, debt tax shields, expected bankruptcy costs, and the extent to which all of these values change when the firm adopts a project. We calculate the magnitude of the distortion in the investment decision, as well as the importance of factors that affect the magnitude of this distortion. In contrast to most empirical studies in corporate finance, which examine the qualitative predictions of various models, this paper derives quantitative predictions from a model that is calibrated to reflect real-world data. 
The results suggest that the distortion in investment decisions arising from managerial risk aversion is significant. In our base-case scenario it is more important than the distortion due to stockholder/debtholder conflicts. The reluctance of a manager to undertake a project generally increases with the project's risk, despite the fact that the magnitude of the wealth transfer from debtholders to stockholders also increases with project risk. Our results are thus consistent with the growing literature suggesting that total firm risk, in addition to systematic risk, is an important factor in the decision-making process (see, for example, Graham and Smith (1999), Shin and Stulz (2000), Goyal and Santa-Clara (2001), and Meulbroek (2001)).

In addition, we find that debt tax shields and bankruptcy costs are important factors in the decision to adopt a project that changes a firm's risk. Both debt tax shields and bankruptcy costs change in value substantially when adoption of a project alters a firm's total risk. Tax shields and bankruptcy costs are often emphasized in the "tradeoff" theory of optimal capital structure. We show that they have other important implications that are not emphasized by the literature. In particular, once a firm's capital structure is in place, risk changes affect the values of both the firm's future debt tax shields and expected bankruptcy costs. The changes in the values of debt tax shields and bankruptcy costs cause managers of levered firms to make different investment decisions than managers of unlevered firms. These changes result in distortions in investment decisions, ex post, in a manner similar to that posited by Jensen and Meckling (1976) and Myers (1977) for wealth transfers between stockholders and debtholders. However, the debt tax shield and bankruptcy cost effects move in the opposite direction from the wealth transfer effect, providing incentives for managers at levered firms to adopt projects that are overly safe, rather than excessively risky.

Our model suggests that once these factors are considered, a manager who holds stock and options in proportion to the median ownership of CEOs at large publicly-traded corporations is likely to behave in an overly risk-averse manner in selecting projects. The manager will accept some safe, negative NPV projects, and reject some risky, positive NPV projects. Three factors, the manager's risk 
aversion, the changes of in the value of tax shields, and changes in the value of expected future bankruptcy costs, each work towards making relatively safe projects more desirable and relatively risky projects less desirable. These three factors provide incentives for managers to avoid additional firm risk, even at the cost of firm value.

We also find that the magnitude of the distortion we document is sensitive to model parameters. Not surprisingly, the choice of the risk-aversion parameter has a large impact. Similarly, the fraction of the manager's wealth outside the firm is an important determinant of the distortion due to managerial risk aversion, as are the project size and debt maturity. Finally, we contribute to the literature on executive compensation by documenting the benefits of options relative to stock grants as means of providing riskaverse managers with incentives to accept risky projects, and how granting in-the-money options can provide managers with incentives to become excessively cautious.

Much work in corporate finance has focused on the existence of distortions in investment resulting from contracting problems. Yet, evaluating the circumstances under which various distortions are important and the circumstances under which they are not has proven to be difficult. This paper applies a quantitative approach to estimating the magnitude of these distortions. Using this approach allows us to identify and evaluate the importance of effects that have not been emphasized by the literature to this point. In particular, once a capital structure is in place, risk changes can have a large impact on the value of existing components of firm value, especially debt tax shields and bankruptcy costs. 


\section{References}

Andrade, Gregor and Steven N. Kaplan, 1998, How costly is financial (not economic) distress? Evidence from highly leveraged transactions that became distressed, Journal of Finance 53, 1443-1493.

Barclay, Michael J., and Clifford W. Smith, Jr., 1995, The maturity structure of corporate debt, Journal of Finance 50, 609-631.

Bettis, Carr, John Bizjak, and Michael Lemmon, 2001, Management ownership, incentive contracting, and the use of zero-cost collars and equity swaps by corporate insiders, Journal of Financial and Quantitative Analysis 36, 345-370.

Black, Fischer and John Cox, 1976, Valuing corporate securities: Some effects of bond indenture provisions, Journal of Finance 31, 351-367.

Carpenter, Jennifer N., 2000, Does option compensation increase managerial risk appetite? Journal of Finance 55, 2311-2332.

Fama, Eugene F., and Merton Miller, 1972, The theory of finance (Dryden Press, Hinsdale, IL).

Goyal, Amit and Pedro Santa-Clara, 2001, Idiosyncratic risk matters, Unpublished manuscript (University of California, Los Angeles).

Graham, John R., 1996, Proxies for the corporate marginal tax rate, Journal of Financial Economics 42, $187-221$.

Graham, John R. and Clifford W. Smith, Jr., 1999, Tax incentives to hedge, Journal of Finance 54, 22412262.

Hall, Brian and Kevin Murphy, 2000, Stock options for undiversified executives, NBER Working Paper No. 8052.

Hamilton, David T., Greg Gupton, and Alexandra Berhault, 2001, Default and recovery rates of corporate bond issuers: 2000, (Moody's Investors Service).

Jensen, Michael C., and William H. Meckling, 1976, Theory of the firm: Managerial behavior, agency costs and ownership structure, Journal of Financial Economics 3, pp. 305-360.

Ju, Nengjiu, 2001, Dynamic optimal capital structure and maturity structure, Unpublished manuscript (University of Maryland).

Leland, Hayne E., 1998. Agency costs, risk management, and capital structure, Journal of Finance 53, 1213-1244.

Leland, Hayne E., and Klaus Toft (1996). Optimal capital structure, endogenous bankruptcy, and the term structure of credit spreads, Journal of Finance 51, 987-1019.

Ljungqvist, Lars, and Thomas J. Sargent, 2000, Recursive macroeconomic theory (The MIT Press, Cambridge, MA) 
Mello, Antonio S., and John E. Parsons, 1992, Measuring the agency cost of debt, Journal of Finance 47, 1887-1904.

Meulbroek, Lisa K., Summer 2001, The efficiency of equity-linked compensation: Understanding the full cost of awarding executive stock options, Financial Management 30, 5-44.

Moyen, Natalie, 2000. Dynamic investment decisions with a tax benefit and a default cost of debt, Unpublished manuscript (University of Colorado).

Myers, Stewart C., 1977, Determinants of corporate borrowing, Journal of Financial Economics 5, 147175.

Parrino, Robert, and Michael S. Weisbach, 1999, Measuring investment distortions arising from stockholder-bondholder conflicts, Journal of Financial Economics 53, 3-42.

Prendergast, Canice, 1999, The provision of incentives in firms, Journal of Economic Literature 37, 7-63.

Shin, Hyun-Han and René M. Stulz, Shareholder wealth and firm risk, Unpublished manuscript (State University of New York at Buffalo and Ohio State University).

Stein, Jeremy, 2001, Agency, information and corporate investment, Handbook of the economics of finance, edited by George Constantinides, Milt Harris, and Rene Stulz (North-Holland, Amsterdam).

Zingales, Luigi, 2000, In search of new foundations, Journal of Finance 55, 1623-1653. 


\section{Appendix}

Closed-form expressions for the integrals defined in equations (14) through (16).

$\mathrm{Ju}$ (2001) derives the following expression for the integrals defined in equations (14) through (16):

$$
\begin{aligned}
& G(T, V(0), A, g, r, \delta, \sigma)=N\left[h_{1}(T, V(0), A, g, r, \delta, \sigma)\right]+\left(\frac{V(0)}{A}\right)^{-2 a(r, \delta, g, \sigma)} N\left[h_{2}(T, V(0), A, g, r, \delta, \sigma)\right] \\
& H(T, V(0), A, g, r, \delta, \sigma)=\left(\frac{V(0)}{A}\right)^{-a(r, \delta, g, \sigma)+z(r, \delta, g, \sigma)} N\left[q_{1}(T, V(0), A, r, \delta, g, \sigma)\right] \\
& +\left(\frac{V(0)}{A}\right)^{-a(r, \delta, g, \sigma)-z(r, \delta, g, \sigma)} N\left[q_{2}(T, V(0), A, r, \delta, g, \sigma)\right] \\
& I(T, V(0), A, g, r, \delta, \sigma)=\left(\frac{V(0)}{A}\right)^{-a(r, \delta, g, \sigma)+\bar{z}(r, \delta, g, \sigma)} N\left[\bar{q}_{1}(T, V(0), A, r, \delta, g, \sigma)\right] \\
& +\left(\frac{V(0)}{A}\right)^{-a(r, \delta, g, \sigma)-\bar{z}(r, \delta, g, \sigma)} N\left[\bar{q}_{2}(T, V(0), A, r, \delta, g, \sigma)\right] \\
& x_{0}(V(0), A)=\log \left(\frac{V(0)}{A}\right) \\
& h_{1}(T, V(0), A, g, r, \delta, \sigma)=\frac{-x_{0}(V(0), A)-a(r, \delta, g, \sigma) \sigma^{2} T}{\sigma \sqrt{T}} \\
& h_{2}(T, V(0), A, g, r, \delta, \sigma)=\frac{-x_{0}(V(0), A)+a(r, \delta, g, \sigma) \sigma^{2} T}{\sigma \sqrt{T}} \\
& q_{1}(T, V(0), A, r, \delta, g, \sigma)=\frac{-x_{0}(V(0), A)-z(r, \delta, g, \sigma) \sigma^{2} T}{\sigma \sqrt{T}} \\
& q_{2}(T, V(0), A, r, \delta, g, \sigma)=\frac{-x_{0}(V(0), A)+z(r, \delta, g, \sigma) \sigma^{2} T}{\sigma \sqrt{T}} \\
& \bar{q}_{1}(T, V(0), A, r, \delta, g, \sigma)=\frac{-x_{0}(V(0), A)-\bar{z}(r, \delta, g, \sigma) \sigma^{2} T}{\sigma \sqrt{T}} \\
& \bar{q}_{2}(T, V(0), A, r, \delta, g, \sigma)=\frac{-x_{0}(V(0), A)+\bar{z}(r, \delta, g, \sigma) \sigma^{2} T}{\sigma \sqrt{T}}
\end{aligned}
$$




$$
\begin{aligned}
& a(r, \delta, g, \sigma)=\frac{\left(r-\delta-g-\sigma^{2} / 2\right)}{\sigma^{2}} \\
& z(r, \delta, g, \sigma)=\frac{\left[\left(a(r, \delta, g, \sigma) \sigma^{2}\right)^{2}+2 r \sigma^{2}\right]^{1 / 2}}{\sigma^{2}} \\
& \bar{z}(r, \delta, g, \sigma)=\frac{\left[\left(a(r, \delta, g, \sigma) \sigma^{2}\right)^{2}+2(r-g) \sigma^{2}\right]^{1 / 2}}{\sigma^{2}}
\end{aligned}
$$

where $N(\bullet)$ is the cumulative standard normal distribution function. 
Table I

Model Parameters

\section{Panel A: Chosen Parameters}

\begin{tabular}{|c|c|c|}
\hline Variable & $\begin{array}{c}\text { Calibrated } \\
\text { Value }\end{array}$ & Variable Description \\
\hline$T_{u}$ & 1 & Time at which manager evaluates utility \\
\hline$T$ & 10 & Time at which debt matures \\
\hline$r$ & 0.0522 & Annualized risk-free rate \\
\hline$V_{N P}(0)$ & $\$ 100$ & Initial value of assets of firm with no project \\
\hline$V_{P}(0)$ & $\$ 120$ & Initial value of assets of firm with project \\
\hline$\mu_{N P}$ & 0.05 & Drift of value of assets of firm with no project \\
\hline$\mu_{P}$ & 0.05 & Drift of value of assets of firm with project \\
\hline$\sigma_{N P}$ & 0.32 & $\begin{array}{l}\text { Volatility of value of assets of firm with no } \\
\text { project }\end{array}$ \\
\hline$\sigma_{P}$ & 0.29695 & $\begin{array}{l}\text { Volatility of value of assets of firm with } \\
\text { project (with } \rho=0.5 \text { ) }\end{array}$ \\
\hline$N_{N P}$ & 100 & Total shares outstanding with no project \\
\hline$F_{N P}$ & $\$ 22.47$ & $\begin{array}{l}\text { Face value of debt with no project (yields } \\
\text { market debt/capital ratio of } 21.90 \% \text { at } \mathrm{T}_{0} \text { ) }\end{array}$ \\
\hline$\gamma$ & 2 & Manager's risk aversion parameter \\
\hline$N_{M a n}\left(<N_{N P}\right)$ & 0.32 & Number of shares owned by manager \\
\hline$N_{\text {Calls }}$ & 0.38 & $\begin{array}{l}\text { Number of exchange traded European calls } \\
\text { owned by manager }\end{array}$ \\
\hline$K$ & $\$ 0.801415$ & Strike price of calls \\
\hline$N F W(0)$ & $\$ 0.256453$ & $\begin{array}{l}\text { Manager's non-firm wealth in dollars at time } \\
\text { zero }\end{array}$ \\
\hline$\alpha_{B C}$ & 0.4806 & 1 - Debtholder bankruptcy recovery rate \\
\hline $\mathrm{g}$ & 0.0519 & Bankruptcy boundary exponential growth rate \\
\hline
\end{tabular}


Table I (continued)

Panel A: Chosen Parameters (continued)

\begin{tabular}{ccl}
\hline $\operatorname{COST}_{P}$ & $\$ 20$ & $\begin{array}{l}\text { Cost of the project in dollars } \\
\tau\end{array}$ \\
DivRate & 0.34 & $\begin{array}{l}\text { Effective tax rate for debt tax shield } \\
\text { Dividend payout rate to equity holders as a } \\
\text { percentage of the unlevered value of the firm. }\end{array}$ \\
\hline
\end{tabular}


Table I (continued)

\section{Panel B: Derived Variables}

\begin{tabular}{|c|c|}
\hline Variable & Variable Description \\
\hline$F_{P}$ & Face value of debt with project \\
\hline$N_{P}$ & Total shares outstanding with project \\
\hline$E_{N P}(0)$ & Initial total value of equity with no project \\
\hline$E_{P}(0)$ & Initial total value of equity with project \\
\hline$D_{N P}(0)$ & Initial total value of debt with no project \\
\hline$D_{P}(0)$ & Initial total value of debt with project \\
\hline$B C_{N P}(0)$ & $\begin{array}{l}\text { Initial total value of bankruptcy costs with no } \\
\text { project }\end{array}$ \\
\hline$B C_{P}(0)$ & $\begin{array}{l}\text { Initial total value of bankruptcy costs with } \\
\text { project }\end{array}$ \\
\hline$T B_{N P}(0)$ & $\begin{array}{l}\text { Initial total value of tax benefits of debt with } \\
\text { no project }\end{array}$ \\
\hline$T B_{P}(0)$ & $\begin{array}{l}\text { Initial total value of tax benefits of debt with } \\
\text { project }\end{array}$ \\
\hline$N F W\left(T_{u}\right)$ & Value of manager's non-firm wealth at time $T_{u}$ \\
\hline$C_{N P}$ & $\begin{array}{l}\text { Constant annualized coupon rate paid by the } \\
\text { debt when there is no project. This is set to } \\
\text { price the debt without the project at par. }\end{array}$ \\
\hline$C_{P}$ & $\begin{array}{l}\text { Constant annualized coupon rate paid by the } \\
\text { debt when the project is accepted }\end{array}$ \\
\hline Utility $_{N P}(0)$ & $\begin{array}{l}\text { Expected future value of manager's utility with } \\
\text { no project }\end{array}$ \\
\hline $\operatorname{Utility}_{P}(0)$ & $\begin{array}{l}\text { Expected future value of manager's utility with } \\
\text { project }\end{array}$ \\
\hline $\operatorname{COST}_{P}^{\text {Indiff }}$ & $\begin{array}{l}\text { The cost of the project at which the manager is } \\
\text { indifferent to taking it }\end{array}$ \\
\hline$\phi_{N P}$ & $\begin{array}{l}\text { Discounted risk-neutral expected value of the } \\
\text { quantity } V_{N P}(T) / V_{N P}(0)\end{array}$ \\
\hline$\phi_{P}$ & $\begin{array}{l}\text { Discounted risk-neutral expected value of the } \\
\text { quantity } V_{P}(T) / V_{P}(0)\end{array}$ \\
\hline$E_{N P}^{\text {Dynamic }}(0)$ & Initial total value of equity with no project \\
\hline
\end{tabular}


Table I (continued)

\section{Panel B: Derived Variables (continued)}

$$
\begin{gathered}
E_{P}^{\text {Dynamic }}(0) \\
B C_{N P}^{\text {Dynamic }}(0) \\
B C_{P}^{\text {Dynamic }}(0) \\
T B_{N P}^{\text {Dynamic }}(0) \\
T B_{P}^{\text {Dynamic }}(0) \\
\delta
\end{gathered}
$$

Initial total value of equity with project

Initial total value of bankruptcy costs with no project

Initial total value of bankruptcy costs with project

Initial total value of tax benefits of debt with no project

Initial total value of tax benefits of debt with project

After tax cash payout rate to both debtholders and equity holders as a percentage of the unlevered value of the firm. 
Table II

Model Output for Projects with Different Volatilities where Market Debt/Equity for Project Financing Equals Market Debt/Equity Ratio of Firm Without Project

Values are for a firm with a value of $\$ 100$ without the project, a project costing $\$ 20$, and a drift parameter for the value of the firm of $5 \%$.

\begin{tabular}{|c|c|c|c|c|c|c|c|c|c|c|c|c|c|c|c|c|c|}
\hline \multirow[b]{2}{*}{ Row } & & \multicolumn{16}{|c|}{ Volatility of Firm Asset Value With Project } \\
\hline & & 0.2667 & 0.2800 & 0.2949 & 0.3110 & 0.3283 & 0.3465 & 0.3655 & 0.3852 & 0.4055 & 0.4263 & 0.4475 & 0.4691 & 0.4910 & 0.5132 & 0.5357 & 0.5583 \\
\hline \multicolumn{18}{|c|}{ Impact of Project on Volatility of Firm Value } \\
\hline 1) & Volatility of Firm Value without Project & 0.3200 & 0.3200 & 0.3200 & 0.3200 & 0.3200 & 0.3200 & 0.3200 & 0.3200 & 0.3200 & 0.3200 & 0.3200 & 0.3200 & 0.3200 & 0.3200 & 0.3200 & 0.3200 \\
\hline 2) & Volatility of Firm Value with Project & 0.2667 & 0.2800 & 0.2949 & 0.3110 & 0.3283 & 0.3465 & 0.3655 & 0.3852 & 0.4055 & 0.4263 & 0.4475 & 0.4691 & 0.4910 & 0.5132 & 0.5357 & 0.5583 \\
\hline \multicolumn{18}{|c|}{ Leverage (Debt/(Debt+Equity)) } \\
\hline 3) & Leverage without Project & $21.90 \%$ & $21.90 \%$ & $21.90 \%$ & $21.90 \%$ & $21.90 \%$ & $21.90 \%$ & $21.90 \%$ & $21.90 \%$ & $21.90 \%$ & $21.90 \%$ & $21.90 \%$ & $21.90 \%$ & $21.90 \%$ & $21.90 \%$ & $21.90 \%$ & $21.90 \%$ \\
\hline 4) & Leverage with Project & $22.52 \%$ & $22.36 \%$ & $22.16 \%$ & $21.94 \%$ & $21.70 \%$ & $21.44 \%$ & $21.16 \%$ & $20.87 \%$ & $20.57 \%$ & $20.26 \%$ & $19.95 \%$ & $19.64 \%$ & $19.32 \%$ & $19.01 \%$ & $18.71 \%$ & $18.41 \%$ \\
\hline \multicolumn{18}{|c|}{ Value of Debt } \\
\hline 5) & Face Value of Debt without Project & $\$ 22.47$ & $\$ 22.47$ & $\$ 22.47$ & $\$ 22.47$ & $\$ 22.47$ & $\$ 22.47$ & $\$ 22.47$ & $\$ 22.47$ & $\$ 22.47$ & $\$ 22.47$ & $\$ 22.47$ & $\$ 22.47$ & $\$ 22.47$ & $\$ 22.47$ & $\$ 22.47$ & $\$ 22.47$ \\
\hline 6) & Initial Value of Debt without Project & $\$ 22.47$ & $\$ 22.47$ & $\$ 22.47$ & $\$ 22.47$ & $\$ 22.47$ & $\$ 22.47$ & $\$ 22.47$ & $\$ 22.47$ & $\$ 22.47$ & $\$ 22.47$ & $\$ 22.47$ & $\$ 22.47$ & $\$ 22.47$ & $\$ 22.47$ & $\$ 22.47$ & $\$ 22.47$ \\
\hline 7) & Face Value of Debt with Project & $\$ 26.61$ & $\$ 26.67$ & $\$ 26.73$ & $\$ 26.81$ & $\$ 26.89$ & $\$ 26.98$ & $\$ 27.08$ & $\$ 27.19$ & $\$ 27.30$ & $\$ 27.43$ & $\$ 27.55$ & $\$ 27.68$ & $\$ 27.82$ & $\$ 27.96$ & $\$ 28.10$ & $\$ 28.25$ \\
\hline 8) & Initial Value of Debt with Project & $\$ 28.16$ & $\$ 27.85$ & $\$ 27.49$ & $\$ 27.10$ & $\$ 26.66$ & $\$ 26.21$ & $\$ 25.73$ & $\$ 25.25$ & $\$ 24.75$ & $\$ 24.25$ & $\$ 23.76$ & $\$ 23.27$ & $\$ 22.79$ & $\$ 22.32$ & $\$ 21.86$ & $\$ 21.42$ \\
\hline 9) & Face Value of New Debt & $\$ 4.14$ & $\$ 4.19$ & $\$ 4.26$ & $\$ 4.33$ & $\$ 4.42$ & $\$ 4.51$ & $\$ 4.61$ & $\$ 4.72$ & $\$ 4.83$ & $\$ 4.95$ & $\$ 5.08$ & $\$ 5.21$ & $\$ 5.35$ & $\$ 5.49$ & $\$ 5.63$ & $\$ 5.78$ \\
\hline 10) & Difference in Value of Debt & $\$ 5.69$ & $\$ 5.38$ & $\$ 5.02$ & $\$ 4.62$ & $\$ 4.19$ & $\$ 3.74$ & $\$ 3.26$ & $\$ 2.77$ & $\$ 2.28$ & $\$ 1.78$ & $\$ 1.29$ & $\$ 0.80$ & $\$ 0.32$ & $-\$ 0.15$ & $-\$ 0.61$ & $-\$ 1.05$ \\
\hline 11) & $\Delta$ Value of Original Debt & $\$ 1.31$ & $\$ 1.00$ & $\$ 0.64$ & $\$ 0.24$ & $-\$ 0.19$ & $-\$ 0.64$ & $-\$ 1.12$ & $-\$ 1.61$ & $-\$ 2.10$ & $-\$ 2.60$ & $-\$ 3.09$ & $-\$ 3.58$ & $-\$ 4.06$ & $-\$ 4.53$ & $-\$ 4.99$ & $-\$ 5.43$ \\
\hline 12) & $\Delta$ Value of Original Debt: Tax Rate $=0$ & $\$ 1.27$ & $\$ 0.96$ & $\$ 0.60$ & $\$ 0.20$ & $-\$ 0.24$ & $-\$ 0.70$ & $-\$ 1.17$ & $-\$ 1.66$ & $-\$ 2.16$ & $-\$ 2.66$ & $-\$ 3.15$ & $-\$ 3.64$ & $-\$ 4.12$ & $-\$ 4.59$ & $-\$ 5.05$ & $-\$ 5.50$ \\
\hline 13) & $\Delta$ Value of Original Debt: $B C=0$ & $\$ 0.41$ & $\$ 0.32$ & $\$ 0.21$ & $\$ 0.09$ & $-\$ 0.06$ & $-\$ 0.22$ & $-\$ 0.39$ & $-\$ 0.58$ & $-\$ 0.78$ & $-\$ 0.98$ & $-\$ 1.19$ & $-\$ 1.41$ & $-\$ 1.63$ & $-\$ 1.85$ & $-\$ 2.07$ & $-\$ 2.29$ \\
\hline 14) & $\triangle$ Value of Original Debt: Tax Rate \& $B C=0$ & $\$ 0.40$ & $\$ 0.31$ & $\$ 0.20$ & $\$ 0.07$ & $-\$ 0.07$ & $-\$ 0.23$ & $-\$ 0.41$ & $-\$ 0.60$ & $-\$ 0.79$ & $-\$ 1.00$ & $-\$ 1.21$ & $-\$ 1.43$ & $-\$ 1.65$ & $-\$ 1.87$ & $-\$ 2.09$ & $-\$ 2.31$ \\
\hline \multicolumn{18}{|c|}{ Value of Equity } \\
\hline 15) & Total Shares Outstanding without Project & 100.00 & 100.00 & 100.00 & 100.00 & 100.00 & 100.00 & 100.00 & 100.00 & 100.00 & 100.00 & 100.00 & 100.00 & 100.00 & 100.00 & 100.00 & 100.00 \\
\hline 16) & Initial Value of Equity without Project & 80.14 & 80.14 & 80.14 & 80.14 & 80.14 & 80.14 & 80.14 & 80.14 & 80.14 & 80.14 & 80.14 & 80.14 & 80.14 & 80.14 & 80.14 & 80.14 \\
\hline 17) & Total Shares Outstanding with Project & 119.22 & 119.26 & 119.30 & 119.34 & 119.39 & 119.43 & 119.47 & 119.50 & 119.54 & 119.57 & 119.59 & 119.62 & 119.64 & 119.66 & 119.68 & 119.69 \\
\hline 18) & Initial Value of Equity with Project & 96.90 & 96.73 & 96.56 & 96.38 & 96.20 & 96.02 & 95.86 & 95.71 & 95.58 & 95.45 & 95.34 & 95.24 & 95.15 & 95.07 & 95.00 & 94.94 \\
\hline 19) & $\Delta$ Value of Original Equity & $\$ 1.14$ & $\$ 0.97$ & $\$ 0.80$ & $\$ 0.61$ & $\$ 0.43$ & $\$ 0.26$ & $\$ 0.10$ & $-\$ 0.05$ & $-\$ 0.18$ & $-\$ 0.31$ & $-\$ 0.42$ & $-\$ 0.52$ & $-\$ 0.61$ & $-\$ 0.69$ & $-\$ 0.76$ & $-\$ 0.82$ \\
\hline 20) & $\Delta$ Value of Original Equity: Tax Rate $=0$ & $-\$ 0.56$ & $-\$ 0.63$ & $-\$ 0.69$ & $-\$ 0.75$ & $-\$ 0.78$ & $-\$ 0.81$ & $-\$ 0.81$ & $-\$ 0.79$ & $-\$ 0.76$ & $-\$ 0.71$ & $-\$ 0.64$ & $-\$ 0.57$ & $-\$ 0.48$ & $-\$ 0.39$ & $-\$ 0.29$ & $-\$ 0.18$ \\
\hline 21) & $\triangle$ Value of Original Equity: $B C=0$ & $\$ 0.93$ & $\$ 0.93$ & $\$ 0.94$ & $\$ 0.95$ & $\$ 0.97$ & $\$ 1.00$ & $\$ 1.04$ & $\$ 1.08$ & $\$ 1.13$ & $\$ 1.19$ & $\$ 1.25$ & $\$ 1.32$ & $\$ 1.39$ & $\$ 1.46$ & $\$ 1.54$ & $\$ 1.61$ \\
\hline 22) & $\triangle$ Value of Original Equity: Tax Rate $\& B C=0$ & $-\$ 0.40$ & $-\$ 0.31$ & $-\$ 0.20$ & $-\$ 0.07$ & $\$ 0.07$ & $\$ 0.23$ & $\$ 0.41$ & $\$ 0.60$ & $\$ 0.79$ & $\$ 1.00$ & $\$ 1.21$ & $\$ 1.43$ & $\$ 1.65$ & $\$ 1.87$ & $\$ 2.09$ & $\$ 2.31$ \\
\hline \multicolumn{18}{|c|}{ Value of Tax Shields } \\
\hline 23) & Total Value of Tax Shields & $\$ 6.30$ & $\$ 6.30$ & $\$ 6.30$ & $\$ 6.30$ & $\$ 6.30$ & $\$ 6.30$ & $\$ 6.30$ & $\$ 6.30$ & $\$ 6.30$ & $\$ 6.30$ & $\$ 6.30$ & $\$ 6.30$ & $\$ 6.30$ & $\$ 6.30$ & $\$ 6.30$ & $\$ 6.30$ \\
\hline 24) & Total Value of Tax Shields with Project & $\$ 7.96$ & $\$ 7.86$ & $\$ 7.75$ & $\$ 7.62$ & $\$ 7.47$ & $\$ 7.32$ & $\$ 7.16$ & $\$ 6.99$ & $\$ 6.81$ & $\$ 6.64$ & $\$ 6.46$ & $\$ 6.28$ & $\$ 6.10$ & $\$ 5.92$ & $\$ 5.74$ & $\$ 5.57$ \\
\hline 25) & Change in Value of Tax Shields & $\$ 1.66$ & $\$ 1.56$ & $\$ 1.44$ & $\$ 1.31$ & $\$ 1.17$ & $\$ 1.01$ & $\$ 0.85$ & $\$ 0.68$ & $\$ 0.51$ & $\$ 0.33$ & $\$ 0.15$ & $-\$ 0.03$ & $-\$ 0.21$ & $-\$ 0.38$ & $-\$ 0.56$ & $-\$ 0.73$ \\
\hline \multicolumn{18}{|c|}{ Bankruptcy Costs } \\
\hline 26) & Bankruptcy Costs without Project & $\$ 3.69$ & $\$ 3.69$ & $\$ 3.69$ & $\$ 3.69$ & $\$ 3.69$ & $\$ 3.69$ & $\$ 3.69$ & $\$ 3.69$ & $\$ 3.69$ & $\$ 3.69$ & $\$ 3.69$ & $\$ 3.69$ & $\$ 3.69$ & $\$ 3.69$ & $\$ 3.69$ & $\$ 3.69$ \\
\hline 27) & Bankru & $\$ 2.90$ & $\$ 3.28$ & $\$ 3.70$ & $\$ 4.14$ & $\$ 4.61$ & $\$ 5.08$ & $\$ 5.56$ & $\$ 6.03$ & $\$ 6.49$ & $\$ 6.93$ & $\$ 7.36$ & $\$ 7.76$ & $\$ 8.15$ & $\$ 8.53$ & $\$ 8.88$ & $\$ 9.21$ \\
\hline 28) & Change in Bankruptcy Costs & $-\$ 0.79$ & $-\$ 0.41$ & $\$ 0.01$ & $\$ 0.45$ & $\$ 0.92$ & $\$ 1.39$ & $\$ 1.87$ & $\$ 2.34$ & $\$ 2.80$ & $\$ 3.24$ & $\$ 3.67$ & $\$ 4.07$ & $\$ 4.47$ & $\$ 4.84$ & $\$ 5.19$ & $\$ 5.52$ \\
\hline \multicolumn{18}{|c|}{ Impact of Project on Manager } \\
\hline 29) & Change in Managers Utility From & 0.0323 & 0.0263 & 0.0195 & 0.0118 & 0.0034 & -0.0057 & -0.0154 & -0.0257 & -0.0366 & -0.0480 & -0.0600 & -0.0725 & -0.0856 & -0.0992 & -0.1133 & -0.1279 \\
\hline 30) & Change in Managers Utility From Zero NPV Project with No Options & 0.0357 & 0.0283 & 0.0201 & 0.0110 & 0.0012 & -0.0093 & -0.0205 & -0.0324 & -0.0453 & -0.0595 & -0.0753 & -0.0931 & -0.1134 & -0.1365 & -0.1627 & -0.1920 \\
\hline 31) & \multicolumn{2}{|c|}{ 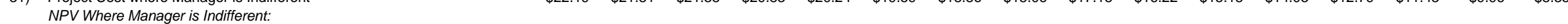 } & & $\$ 21.35$ & $\$ 20.83$ & $\$ 20.24$ & $\$ 19.59$ & $\$ 18.86$ & $\$ 18.06$ & $\$ 17.18$ & $\$ 16.22$ & $\$ 15.18$ & $\$ 14.03$ & $\$ 12.79$ & $\$ 11.43$ & $\$ 9.96$ & $\$ 8.35$ \\
\hline 32) & Base Case & $-\$ 2.19$ & $-\$ 1.81$ & $-\$ 1.35$ & $-\$ 0.83$ & $-\$ 0.24$ & $\$ 0.41$ & $\$ 1.14$ & $\$ 1.94$ & $\$ 2.82$ & $\$ 3.78$ & $\$ 4.82$ & $\$ 5.97$ & $\$ 7.21$ & $\$ 8.57$ & $\$ 10.04$ & $\$ 11.65$ \\
\hline 33) & Tax Rate $=0$ & $-\$ 0.37$ & $-\$ 0.09$ & $\$ 0.22$ & $\$ 0.58$ & $\$ 0.99$ & $\$ 1.44$ & $\$ 1.94$ & $\$ 2.49$ & $\$ 3.10$ & $\$ 3.77$ & $\$ 4.51$ & $\$ 5.32$ & $\$ 6.22$ & $\$ 7.21$ & $\$ 8.30$ & $\$ 9.50$ \\
\hline 34$)$ & $B C=0$ & $-\$ 1.87$ & $-\$ 1.68$ & $-\$ 1.44$ & $-\$ 1.15$ & $-\$ 0.81$ & $-\$ 0.40$ & $\$ 0.08$ & $\$ 0.63$ & $\$ 1.26$ & $\$ 1.97$ & $\$ 2.77$ & $\$ 3.67$ & $\$ 4.66$ & $\$ 5.77$ & $\$ 7.00$ & $\$ 8.36$ \\
\hline 35$)$ & $B C \& \operatorname{Tax} R$ & $-\$ 0.41$ & $-\$ 0.34$ & $-\$ 0.23$ & $-\$ 0.09$ & $\$ 0.09$ & $\$ 0.32$ & $\$ 0.60$ & $\$ 0.93$ & $\$ 1.33$ & $\$ 1.80$ & $\$ 2.35$ & $\$ 2.97$ & $\$ 3.69$ & $\$ 4.50$ & $\$ 5.42$ & $\$ 6.45$ \\
\hline 36) & Risk Neutral Manager, BC \& Tax Rate $=0$ & $\$ 1.96$ & $\$ 1.47$ & $\$ 0.93$ & $\$ 0.33$ & $-\$ 0.30$ & $-\$ 0.97$ & $-\$ 1.67$ & $-\$ 2.38$ & $-\$ 3.11$ & $-\$ 3.85$ & $-\$ 4.60$ & $-\$ 5.36$ & $-\$ 6.11$ & $-\$ 6.87$ & $-\$ 7.62$ & $-\$ 8.37$ \\
\hline 37) & $\begin{array}{l}\text { Risk Neutral Manager Owns No Options, BC \& Tax Rate }=0 \\
\text { Incremental Cost of Equity Where Manager is Indifferent: }\end{array}$ & $\$ 0.44$ & $\$ 0.34$ & $\$ 0.22$ & $\$ 0.08$ & $-\$ 0.08$ & $-\$ 0.25$ & $-\$ 0.45$ & $-\$ 0.65$ & $-\$ 0.87$ & $-\$ 1.10$ & $-\$ 1.33$ & $-\$ 1.57$ & $-\$ 1.81$ & $-\$ 2.05$ & $-\$ 2.29$ & $-\$ 2.53$ \\
\hline 38) & Base Case & $-0.66 \%$ & $-0.56 \%$ & $-0.43 \%$ & $-0.27 \%$ & $-0.08 \%$ & $0.14 \%$ & $0.40 \%$ & $0.71 \%$ & $1.09 \%$ & $1.54 \%$ & $2.10 \%$ & $2.80 \%$ & $3.71 \%$ & $4.91 \%$ & $6.60 \%$ & $9.12 \%$ \\
\hline 39) & Tax Rate $=0$ & $-0.12 \%$ & $-0.03 \%$ & $0.08 \%$ & $0.21 \%$ & $0.36 \%$ & $0.52 \%$ & $0.72 \%$ & $0.96 \%$ & $1.23 \%$ & $1.55 \%$ & $1.94 \%$ & $2.41 \%$ & $2.99 \%$ & $3.73 \%$ & $4.68 \%$ & $5.96 \%$ \\
\hline 40) & $B C=0$ & $-0.57 \%$ & $-0.52 \%$ & $-0.45 \%$ & $-0.36 \%$ & $-0.26 \%$ & $-0.13 \%$ & $0.03 \%$ & $0.22 \%$ & $0.45 \%$ & $0.72 \%$ & $1.07 \%$ & $1.49 \%$ & $2.01 \%$ & $2.68 \%$ & $3.55 \%$ & $4.73 \%$ \\
\hline 41) & $B C \&$ Tax Rate $=$ & $-0.14 \%$ & $-0.11 \%$ & $-0.08 \%$ & $-0.03 \%$ & $0.03 \%$ & $0.11 \%$ & $0.21 \%$ & $0.33 \%$ & $0.48 \%$ & $0.66 \%$ & $0.89 \%$ & $1.16 \%$ & $1.51 \%$ & $1.93 \%$ & $2.47 \%$ & $3.16 \%$ \\
\hline 42) & Risk Neutral Manager, BC \& Tax Rate $=0$ & $0.73 \%$ & $0.54 \%$ & $0.33 \%$ & $0.11 \%$ & $-0.10 \%$ & $-0.31 \%$ & $-0.52 \%$ & $-0.71 \%$ & $-0.90 \%$ & $-1.08 \%$ & $-1.25 \%$ & $-1.41 \%$ & $-1.56 \%$ & $-1.70 \%$ & $-1.83 \%$ & $-1.96 \%$ \\
\hline 43) & Risk Neutral Manager Owns No Options, $B C \&$ Tax Rate $=0$ & $0.15 \%$ & $0.12 \%$ & $0.08 \%$ & $0.03 \%$ & $-0.03 \%$ & $-0.08 \%$ & $-0.15 \%$ & $-0.21 \%$ & $-0.28 \%$ & $-0.35 \%$ & $-0.42 \%$ & $-0.48 \%$ & $-0.55 \%$ & $-0.62 \%$ & $-0.68 \%$ & $-0.74 \%$ \\
\hline
\end{tabular}


Table III

Model Output for Projects with Different Volatilities where the Debtholders of the Firm Without the Project are Made Whole

Values are for a firm with a value of $\$ 100$ without the project, a project costing $\$ 20$, and a drift parameter for the value of the firm of $5 \%$.

\begin{tabular}{|c|c|c|c|c|c|c|c|c|c|c|c|c|c|c|c|c|c|}
\hline \multirow[b]{2}{*}{ Row } & & \multicolumn{16}{|c|}{ Volatility of Firm Asset Value With Project } \\
\hline & & 0.2667 & 0.2800 & 0.2949 & 0.3110 & 0.3283 & 0.3465 & 0.3655 & 0.3852 & 0.4055 & 0.4263 & 0.4475 & 0.4691 & 0.4910 & 0.5132 & 0.5357 & 0.5583 \\
\hline \multicolumn{18}{|c|}{ Impact of Project on Volatility of Firm Value } \\
\hline 1) & Volatility of Firm Value without Project & 0.3200 & 0.3200 & 0.3200 & 0.3200 & 0.3200 & 0.3200 & 0.3200 & 0.3200 & 0.3200 & 0.3200 & 0.3200 & 0.3200 & 0.3200 & 0.3200 & 0.3200 & 0.3200 \\
\hline 2) & Volatility of Firm Value with Project & 0.2667 & 0.2800 & 0.2949 & 0.3110 & 0.3283 & 0.3465 & 0.3655 & 0.3852 & 0.4055 & 0.4263 & 0.4475 & 0.4691 & 0.4910 & 0.5132 & 0.5357 & 0.5583 \\
\hline \multicolumn{18}{|c|}{ Leverage (Debt/(Debt+Equity)) } \\
\hline 3) & Leverage without Project & $21.90 \%$ & $21.90 \%$ & $21.90 \%$ & $21.90 \%$ & $21.90 \%$ & $21.90 \%$ & $21.90 \%$ & $21.90 \%$ & $21.90 \%$ & $21.90 \%$ & $21.90 \%$ & $21.90 \%$ & $21.90 \%$ & $21.90 \%$ & $21.90 \%$ & $21.90 \%$ \\
\hline 4) & Leverage with Project & $28.71 \%$ & $26.89 \%$ & $24.96 \%$ & $22.96 \%$ & $20.95 \%$ & $18.97 \%$ & $17.05 \%$ & $15.22 \%$ & $13.50 \%$ & $11.89 \%$ & $10.41 \%$ & $9.06 \%$ & $7.83 \%$ & $6.73 \%$ & $5.76 \%$ & $4.89 \%$ \\
\hline \multicolumn{18}{|c|}{ Value of Debt } \\
\hline 5) & Face Value of Debt without Project & $\$ 22.47$ & $\$ 22.47$ & $\$ 22.47$ & $\$ 22.47$ & $\$ 22.47$ & $\$ 22.47$ & $\$ 22.47$ & $\$ 22.47$ & $\$ 22.47$ & $\$ 22.47$ & $\$ 22.47$ & $\$ 22.47$ & $\$ 22.47$ & $\$ 22.47$ & $\$ 22.47$ & $\$ 22.47$ \\
\hline 6) & Initial Value of Debt without Project & $\$ 22.47$ & $\$ 22.47$ & $\$ 22.47$ & $\$ 22.47$ & $\$ 22.47$ & $\$ 22.47$ & $\$ 22.47$ & $\$ 22.47$ & $\$ 22.47$ & $\$ 22.47$ & $\$ 22.47$ & $\$ 22.47$ & $\$ 22.47$ & $\$ 22.47$ & $\$ 22.47$ & $\$ 22.47$ \\
\hline 7) & Face Value of Debt with Project & $\$ 35.61$ & $\$ 33.29$ & $\$ 30.83$ & $\$ 28.31$ & $\$ 25.77$ & $\$ 23.29$ & $\$ 20.89$ & $\$ 18.61$ & $\$ 16.46$ & $\$ 14.48$ & $\$ 12.65$ & $\$ 10.99$ & $\$ 9.49$ & $\$ 8.15$ & $\$ 6.96$ & $\$ 5.91$ \\
\hline 8) & Initial Value of Debt with Project & $\$ 35.61$ & $\$ 33.29$ & $\$ 30.83$ & $\$ 28.31$ & $\$ 25.77$ & $\$ 23.29$ & $\$ 20.89$ & $\$ 18.61$ & $\$ 16.46$ & $\$ 14.48$ & $\$ 12.65$ & $\$ 10.99$ & $\$ 9.49$ & $\$ 8.15$ & $\$ 6.96$ & $\$ 5.91$ \\
\hline 9) & Face Value of New Debt & $\$ 13.14$ & $\$ 10.82$ & $\$ 8.36$ & $\$ 5.83$ & $\$ 3.30$ & $\$ 0.81$ & $-\$ 1.59$ & $-\$ 3.87$ & $-\$ 6.01$ & $-\$ 8.00$ & $-\$ 9.82$ & $-\$ 11.48$ & $-\$ 12.98$ & $-\$ 14.32$ & $-\$ 15.52$ & $-\$ 16.57$ \\
\hline 10) & Difference in Value of Debt & $\$ 13.14$ & $\$ 10.82$ & $\$ 8.36$ & $\$ 5.83$ & $\$ 3.30$ & $\$ 0.81$ & $-\$ 1.59$ & $-\$ 3.87$ & $-\$ 6.01$ & $-\$ 8.00$ & $-\$ 9.82$ & $-\$ 11.48$ & $-\$ 12.98$ & $-\$ 14.32$ & $-\$ 15.52$ & $-\$ 16.57$ \\
\hline 11) & $\Delta$ Value of Original Debt & $\$ 0.00$ & $\$ 0.00$ & $\$ 0.00$ & $\$ 0.00$ & $\$ 0.00$ & $\$ 0.00$ & $\$ 0.00$ & $\$ 0.00$ & $\$ 0.00$ & $\$ 0.00$ & $\$ 0.00$ & $\$ 0.00$ & $\$ 0.00$ & $\$ 0.00$ & $\$ 0.00$ & $\$ 0.00$ \\
\hline 12) & $\Delta$ Value of Original Debt: Tax Rate $=0$ & $\$ 0.00$ & $\$ 0.00$ & $\$ 0.00$ & $\$ 0.00$ & $\$ 0.00$ & $\$ 0.00$ & $\$ 0.00$ & $\$ 0.00$ & $\$ 0.00$ & $\$ 0.00$ & $\$ 0.00$ & $\$ 0.00$ & $\$ 0.00$ & $\$ 0.00$ & $\$ 0.00$ & $\$ 0.00$ \\
\hline 13) & $\Delta$ Value of Original Debt: $B C=0$ & $\$ 0.00$ & $\$ 0.00$ & $\$ 0.00$ & $\$ 0.00$ & $\$ 0.00$ & $\$ 0.00$ & $\$ 0.00$ & $\$ 0.00$ & $\$ 0.00$ & $\$ 0.00$ & $\$ 0.00$ & $\$ 0.00$ & $\$ 0.00$ & $\$ 0.00$ & $\$ 0.00$ & $\$ 0.00$ \\
\hline 14) & $\triangle$ Value of Original Debt: Tax Rate $\& B C=0$ & $\$ 0.00$ & $\$ 0.00$ & $\$ 0.00$ & $\$ 0.00$ & $\$ 0.00$ & $\$ 0.00$ & $\$ 0.00$ & $\$ 0.00$ & $\$ 0.00$ & $\$ 0.00$ & $\$ 0.00$ & $\$ 0.00$ & $\$ 0.00$ & $\$ 0.00$ & $\$ 0.00$ & $\$ 0.00$ \\
\hline \multicolumn{18}{|c|}{ Value of Equity } \\
\hline 15) & Total Shares Outstanding without Project & 100.00 & 100.00 & 100.00 & 100.00 & 100.00 & 100.00 & 100.00 & 100.00 & 100.00 & 100.00 & 100.00 & 100.00 & 100.00 & 100.00 & 100.00 & 100.00 \\
\hline 16) & Initial Value of Equity without Project & 80.14 & 80.14 & 80.14 & 80.14 & 80.14 & 80.14 & 80.14 & 80.14 & 80.14 & 80.14 & 80.14 & 80.14 & 80.14 & 80.14 & 80.14 & 80.14 \\
\hline 17) & Total Shares Outstanding with Project & 108.42 & 111.29 & 114.36 & 117.53 & 120.74 & 123.90 & 126.98 & 129.93 & 132.72 & 135.32 & 137.72 & 139.92 & 141.92 & 143.72 & 145.32 & 146.73 \\
\hline 18) & Initial Value of Equity with Project & 88.41 & 90.50 & 92.71 & 94.97 & 97.24 & 99.45 & 101.59 & 103.61 & 105.51 & 107.26 & 108.88 & 110.34 & 111.66 & 112.84 & 113.89 & 114.81 \\
\hline 19) & $\triangle$ Value of Original Equity & $\$ 1.41$ & $\$ 1.18$ & $\$ 0.93$ & $\$ 0.66$ & $\$ 0.39$ & $\$ 0.12$ & $-\$ 0.14$ & $-\$ 0.40$ & $-\$ 0.64$ & $-\$ 0.87$ & $-\$ 1.09$ & $-\$ 1.28$ & $-\$ 1.46$ & $-\$ 1.62$ & $-\$ 1.77$ & $-\$ 1.89$ \\
\hline 20) & $\Delta$ Value of Original Equity: Tax Rate $=0$ & $-\$ 2.09$ & $-\$ 1.73$ & $-\$ 1.34$ & $-\$ 0.95$ & $-\$ 0.55$ & $-\$ 0.16$ & $\$ 0.22$ & $\$ 0.59$ & $\$ 0.93$ & $\$ 1.25$ & $\$ 1.55$ & $\$ 1.82$ & $\$ 2.07$ & $\$ 2.29$ & $\$ 2.49$ & $\$ 2.67$ \\
\hline 21) & $\triangle$ Value of Original Equity: $B C=0$ & $\$ 2.85$ & $\$ 2.36$ & $\$ 1.84$ & $\$ 1.30$ & $\$ 0.75$ & $\$ 0.21$ & $-\$ 0.31$ & $-\$ 0.81$ & $-\$ 1.28$ & $-\$ 1.73$ & $-\$ 2.13$ & $-\$ 2.50$ & $-\$ 2.84$ & $-\$ 3.14$ & $-\$ 3.41$ & $-\$ 3.65$ \\
\hline 22) & $\triangle$ Value of Original Equity: Tax Rate $\& B C=0$ & $\$ 0.00$ & $\$ 0.00$ & $\$ 0.00$ & $\$ 0.00$ & $\$ 0.00$ & $\$ 0.00$ & $\$ 0.00$ & $\$ 0.00$ & $\$ 0.00$ & $\$ 0.00$ & $\$ 0.00$ & $\$ 0.00$ & $\$ 0.00$ & $\$ 0.00$ & $\$ 0.00$ & $\$ 0.00$ \\
\hline \multicolumn{18}{|c|}{ Value of Tax Shields } \\
\hline 23) & Total Value of Tax Shields without Project & $\$ 6.30$ & $\$ 6.30$ & $\$ 6.30$ & $\$ 6.30$ & $\$ 6.30$ & $\$ 6.30$ & $\$ 6.30$ & $\$ 6.30$ & $\$ 6.30$ & $\$ 6.30$ & $\$ 6.30$ & $\$ 6.30$ & $\$ 6.30$ & $\$ 6.30$ & $\$ 6.30$ & $\$ 6.30$ \\
\hline 24) & Total Value of Tax Shields v & $\$ 9.80$ & $\$ 9.21$ & $\$ 8.58$ & $\$ 7.92$ & $\$ 7.25$ & $\$ 6.59$ & $\$ 5.94$ & $\$ 5.32$ & $\$ 4.73$ & $\$ 4.18$ & $\$ 3.67$ & $\$ 3.20$ & $\$ 2.77$ & $\$ 2.39$ & $\$ 2.04$ & $\$ 1.74$ \\
\hline 25) & Change in Value of Tax Shields & $\$ 3.50$ & $\$ 2.91$ & $\$ 2.27$ & $\$ 1.61$ & $\$ 0.94$ & $\$ 0.28$ & $-\$ 0.37$ & $-\$ 0.99$ & $-\$ 1.58$ & $-\$ 2.13$ & $-\$ 2.64$ & $-\$ 3.11$ & $-\$ 3.53$ & $-\$ 3.92$ & $-\$ 4.26$ & $-\$ 4.56$ \\
\hline \multicolumn{18}{|c|}{ Bankruptcy Costs } \\
\hline 26) & Bankruptcy Costs without Projec & $\$ 3.69$ & $\$ 3.69$ & $\$ 3.69$ & $\$ 3.69$ & $\$ 3.69$ & $\$ 3.69$ & $\$ 3.69$ & $\$ 3.69$ & $\$ 3.69$ & $\$ 3.69$ & $\$ 3.69$ & $\$ 3.69$ & $\$ 3.69$ & $\$ 3.69$ & $\$ 3.69$ & $\$ 3.69$ \\
\hline 27) & Bankruptcy Costs with Project & $\$ 5.78$ & $\$ 5.42$ & $\$ 5.03$ & $\$ 4.64$ & $\$ 4.24$ & $\$ 3.85$ & $\$ 3.47$ & $\$ 3.10$ & $\$ 2.76$ & $\$ 2.43$ & $\$ 2.14$ & $\$ 1.87$ & $\$ 1.62$ & $\$ 1.40$ & $\$ 1.20$ & $\$ 1.02$ \\
\hline 28) & Change in Bankruptcy Costs & $\$ 2.09$ & $\$ 1.73$ & $\$ 1.34$ & $\$ 0.95$ & $\$ 0.55$ & $\$ 0.16$ & $-\$ 0.22$ & $-\$ 0.59$ & $-\$ 0.93$ & $-\$ 1.25$ & $-\$ 1.55$ & $-\$ 1.82$ & $-\$ 2.07$ & $-\$ 2.29$ & $-\$ 2.49$ & $-\$ 2.67$ \\
\hline \multicolumn{18}{|c|}{ Impact of Project on Manager } \\
\hline 29) & Change in Managers Utility From Zerc & 0.0229 & 0.0192 & 0.0149 & 0.0101 & 0.0047 & -0.0010 & -0.0072 & -0.0137 & -0.0206 & -0.0277 & -0.0352 & -0.0429 & -0.0510 & -0.0593 & -0.0680 & -0.0769 \\
\hline 30) & Change in Managers Utility From Zero NPV Project with No Options & 0.0223 & 0.0183 & 0.0137 & 0.0086 & 0.0030 & -0.0030 & -0.0094 & -0.0162 & -0.0233 & -0.0306 & -0.0383 & -0.0463 & -0.0545 & -0.0631 & -0.0719 & -0.0810 \\
\hline \multicolumn{18}{|c|}{$\begin{array}{l}\$ 21.59 \\
\$ 21.34\end{array}$} \\
\hline 32) & Base Case & $-\$ 1.59$ & $-\$ 1.34$ & $-\$ 1.05$ & $-\$ 0.71$ & $-\$ 0.34$ & $\$ 0.07$ & $\$ 0.52$ & $\$ 1.01$ & $\$ 1.52$ & $\$ 2.08$ & $\$ 2.67$ & $\$ 3.29$ & $\$ 3.96$ & $\$ 4.67$ & $\$ 5.43$ & $\$ 6.24$ \\
\hline 33) & Tax Rate $=0$ & $\$ 2.06$ & $\$ 2.06$ & $\$ 2.06$ & $\$ 2.06$ & $\$ 2.06$ & $\$ 2.06$ & $\$ 2.06$ & $\$ 2.06$ & $\$ 2.06$ & $\$ 2.06$ & $\$ 2.06$ & $\$ 2.06$ & $\$ 2.06$ & $\$ 2.06$ & $\$ 2.06$ & $\$ 2.06$ \\
\hline 34) & $B C=0$ & $-\$ 3.06$ & $-\$ 2.55$ & $-\$ 1.98$ & $-\$ 1.35$ & $-\$ 0.68$ & $\$ 0.03$ & $\$ 0.78$ & $\$ 1.56$ & $\$ 2.36$ & $\$ 3.19$ & $\$ 4.04$ & $\$ 4.92$ & $\$ 5.83$ & $\$ 6.78$ & $\$ 7.76$ & $\$ 8.78$ \\
\hline 35) & $B C \&$ Tax Rate $=0$ & $-\$ 0.17$ & $-\$ 0.17$ & $-\$ 0.17$ & $-\$ 0.17$ & $-\$ 0.17$ & $-\$ 0.17$ & $-\$ 0.17$ & $-\$ 0.17$ & $-\$ 0.17$ & $-\$ 0.17$ & $-\$ 0.17$ & $-\$ 0.17$ & $-\$ 0.17$ & $-\$ 0.17$ & $-\$ 0.17$ & $-\$ 0.17$ \\
\hline 36) & Risk Neutral Manager, BC \& Tax Rate & $\$ 1.13$ & $\$ 0.83$ & $\$ 0.52$ & $\$ 0.18$ & $-\$ 0.17$ & $-\$ 0.52$ & $-\$ 0.89$ & $-\$ 1.26$ & $-\$ 1.64$ & $-\$ 2.02$ & $-\$ 2.41$ & $-\$ 2.81$ & $-\$ 3.21$ & $-\$ 3.61$ & $-\$ 4.02$ & $-\$ 4.44$ \\
\hline 37) & \multicolumn{17}{|l|}{ Incremental Cost of Equity Where Manager is Indifferent: } \\
\hline 38) & Base Case & $-0.53 \%$ & $-0.45 \%$ & $-0.35 \%$ & $-0.23 \%$ & $-0.11 \%$ & $0.02 \%$ & $0.17 \%$ & $0.34 \%$ & $0.52 \%$ & $0.72 \%$ & $0.95 \%$ & $1.21 \%$ & $1.50 \%$ & $1.84 \%$ & $2.24 \%$ & $2.72 \%$ \\
\hline 39) & Tax Rate $=0$ & $0.87 \%$ & $0.66 \%$ & $0.49 \%$ & $0.34 \%$ & $0.20 \%$ & $0.09 \%$ & $0.01 \%$ & $-0.06 \%$ & $-0.11 \%$ & $-0.13 \%$ & $-0.14 \%$ & $-0.12 \%$ & $-0.09 \%$ & $-0.03 \%$ & $0.05 \%$ & $0.16 \%$ \\
\hline 40) & $B C=0$ & $-0.95 \%$ & $-0.80 \%$ & $-0.63 \%$ & $-0.43 \%$ & $-0.22 \%$ & $0.01 \%$ & $0.26 \%$ & $0.54 \%$ & $0.84 \%$ & $1.18 \%$ & $1.56 \%$ & $2.00 \%$ & $2.51 \%$ & $3.10 \%$ & $3.81 \%$ & $4.69 \%$ \\
\hline 41) & $B C \&$ Tax Rate $=0$ & $-0.06 \%$ & $-0.06 \%$ & $-0.04 \%$ & $-0.02 \%$ & $0.02 \%$ & $0.06 \%$ & $0.12 \%$ & $0.19 \%$ & $0.27 \%$ & $0.37 \%$ & $0.49 \%$ & $0.64 \%$ & $0.80 \%$ & $1.00 \%$ & $1.24 \%$ & $1.52 \%$ \\
\hline 42) & Risk Neutral Manager, BC \& Tax Ra & $0.45 \%$ & $0.31 \%$ & $0.19 \%$ & $0.06 \%$ & $-0.05 \%$ & $-0.17 \%$ & $-0.27 \%$ & $-0.38 \%$ & $-0.48 \%$ & $-0.57 \%$ & $-0.66 \%$ & $-0.75 \%$ & $-0.84 \%$ & $-0.93 \%$ & $-1.01 \%$ & $-1.09 \%$ \\
\hline 43) & Risk Neutral Manager Owns No Options, $B C \&$ Tax Rate $=0$ & $0.13 \%$ & $0.09 \%$ & $0.05 \%$ & $0.02 \%$ & $-0.01 \%$ & $-0.04 \%$ & $-0.06 \%$ & $-0.08 \%$ & $-0.10 \%$ & $-0.12 \%$ & $-0.13 \%$ & $-0.14 \%$ & $-0.15 \%$ & $-0.16 \%$ & $-0.16 \%$ & $-0.17 \%$ \\
\hline
\end{tabular}


Table IV

Model Output for Projects with Different Volatilities Where Leverage Remains Constant

Values are for a firm with a value of $\$ 100$ without the project, a project costing $\$ 20$, and a drift parameter for the value of the firm of $5 \%$.

\begin{tabular}{|c|c|c|c|c|c|c|c|c|c|c|c|c|c|c|c|c|c|}
\hline \multirow[b]{2}{*}{ Row } & & \multicolumn{16}{|c|}{ f Firm Asset Value With Project } \\
\hline & & 0.2667 & 0.2800 & 0.2949 & 0.3110 & 0.3283 & 0.3465 & 0.3655 & 0.3852 & 0.4055 & 0.4263 & 0.4475 & 0.4691 & 0.4910 & 0.5132 & 0.5357 & 0.5583 \\
\hline \multicolumn{18}{|c|}{ Impact of Project on Volatility of Firm Value } \\
\hline 1) & Volatility of Firm Value without Project & 0.3200 & 0.3200 & 0.3200 & 0.3200 & 0.3200 & 0.3200 & 0.3200 & 0.3200 & 0.3200 & 0.3200 & 0.3200 & 0.3200 & 0.3200 & 0.3200 & 0.3200 & 0.3200 \\
\hline & Volatility of Firm Value with Project & 0.2667 & 0.2800 & 0.2949 & 0.3110 & 0.3283 & 0.3465 & 0.3655 & 0.3852 & 0.4055 & 0.4263 & 0.4475 & 0.4691 & 0.4910 & 0.5132 & 0.5357 & 0.5583 \\
\hline \multicolumn{18}{|c|}{ Leverage (Debt/(Debt+Equity)) } \\
\hline 3) & Leverage without Project & $21.90 \%$ & $21.90 \%$ & $21.90 \%$ & $21.90 \%$ & $21.90 \%$ & $21.90 \%$ & $21.90 \%$ & $21.90 \%$ & $21.90 \%$ & $21.90 \%$ & $21.90 \%$ & $21.90 \%$ & $21.90 \%$ & $21.90 \%$ & $21.90 \%$ & $21.90 \%$ \\
\hline 4) & Leverage with Project & $21.90 \%$ & $21.90 \%$ & $21.90 \%$ & $21.90 \%$ & $21.90 \%$ & $21.90 \%$ & $21.90 \%$ & $21.90 \%$ & $21.90 \%$ & $21.90 \%$ & $21.90 \%$ & $21.90 \%$ & $21.90 \%$ & $21.90 \%$ & $21.90 \%$ & $21.90 \%$ \\
\hline \multicolumn{18}{|c|}{ Value of Debt } \\
\hline 5) & Face Value of Debt without Project & $\$ 22.47$ & $\$ 22.47$ & $\$ 22.47$ & $\$ 22.47$ & $\$ 22.47$ & $\$ 22.47$ & $\$ 22.47$ & $\$ 22.47$ & $\$ 22.47$ & $\$ 22.47$ & $\$ 22.47$ & $\$ 22.47$ & $\$ 22.47$ & $\$ 22.47$ & $\$ 22.47$ & $\$ 22.47$ \\
\hline 6) & Initial Value of Debt without Project & $\$ 22.47$ & $\$ 22.47$ & $\$ 22.47$ & $\$ 22.47$ & $\$ 22.47$ & $\$ 22.47$ & $\$ 22.47$ & $\$ 22.47$ & $\$ 22.47$ & $\$ 22.47$ & $\$ 22.47$ & $\$ 22.47$ & $\$ 22.47$ & $\$ 22.47$ & $\$ 22.47$ & $\$ 22.47$ \\
\hline 7) & Face Value of Debt with Project & $\$ 25.76$ & $\$ 26.03$ & $\$ 26.35$ & $\$ 26.74$ & $\$ 27.18$ & $\$ 27.68$ & $\$ 28.24$ & $\$ 28.84$ & $\$ 29.50$ & $\$ 30.19$ & $\$ 30.92$ & $\$ 31.69$ & $\$ 32.48$ & $\$ 33.30$ & $\$ 34.13$ & $\$ 34.98$ \\
\hline 8) & Initial Value of Debt with Project & $\$ 27.40$ & $\$ 27.29$ & $\$ 27.17$ & $\$ 27.04$ & $\$ 26.90$ & $\$ 26.74$ & $\$ 26.58$ & $\$ 26.42$ & $\$ 26.25$ & $\$ 26.08$ & $\$ 25.90$ & $\$ 25.73$ & $\$ 25.56$ & $\$ 25.39$ & $\$ 25.22$ & $\$ 25.06$ \\
\hline 9) & Face Value of New Debt & $\$ 3.28$ & $\$ 3.55$ & $\$ 3.88$ & $\$ 4.27$ & $\$ 4.71$ & $\$ 5.21$ & $\$ 5.77$ & $\$ 6.37$ & $\$ 7.02$ & $\$ 7.72$ & $\$ 8.45$ & $\$ 9.22$ & $\$ 10.01$ & $\$ 10.83$ & $\$ 11.66$ & $\$ 12.51$ \\
\hline 10) & Difference in Value of Debt & $\$ 4.92$ & $\$ 4.82$ & $\$ 4.70$ & $\$ 4.57$ & $\$ 4.43$ & $\$ 4.27$ & $\$ 4.11$ & $\$ 3.94$ & $\$ 3.77$ & $\$ 3.60$ & $\$ 3.43$ & $\$ 3.26$ & $\$ 3.09$ & $\$ 2.92$ & $\$ 2.75$ & $\$ 2.58$ \\
\hline 11) & $\Delta$ Value of Original Debt & $\$ 1.43$ & $\$ 1.09$ & $\$ 0.70$ & $\$ 0.25$ & $-\$ 0.24$ & $-\$ 0.76$ & $-\$ 1.32$ & $-\$ 1.89$ & $-\$ 2.48$ & $-\$ 3.06$ & $-\$ 3.65$ & $-\$ 4.23$ & $-\$ 4.79$ & $-\$ 5.34$ & $-\$ 5.87$ & $-\$ 6.38$ \\
\hline 12) & $\triangle$ Value of Original Debt: Tax Rate $=0$ & $\$ 1.43$ & $\$ 1.10$ & $\$ 0.70$ & $\$ 0.25$ & $-\$ 0.24$ & $-\$ 0.77$ & $-\$ 1.32$ & $-\$ 1.90$ & $-\$ 2.49$ & $-\$ 3.08$ & $-\$ 3.67$ & $-\$ 4.25$ & $-\$ 4.82$ & $-\$ 5.37$ & $-\$ 5.91$ & $-\$ 6.42$ \\
\hline 13) & $\triangle$ Value of Original Debt: $B C=0$ & $\$ 0.42$ & $\$ 0.32$ & $\$ 0.21$ & $\$ 0.08$ & $-\$ 0.07$ & $-\$ 0.25$ & $-\$ 0.43$ & $-\$ 0.64$ & $-\$ 0.85$ & $-\$ 1.08$ & $-\$ 1.31$ & $-\$ 1.55$ & $-\$ 1.79$ & $-\$ 2.03$ & $-\$ 2.27$ & $-\$ 2.51$ \\
\hline 14) & $\triangle$ Value of Original Debt: Tax Rate \& $B C=0$ & $\$ 0.42$ & $\$ 0.33$ & $\$ 0.21$ & $\$ 0.08$ & $-\$ 0.08$ & $-\$ 0.25$ & $-\$ 0.44$ & $-\$ 0.64$ & $-\$ 0.86$ & $-\$ 1.09$ & $-\$ 1.32$ & $-\$ 1.56$ & $-\$ 1.81$ & $-\$ 2.06$ & $-\$ 2.30$ & $-\$ 2.54$ \\
\hline \multicolumn{18}{|c|}{ Value of Equity } \\
\hline 15) & Total Shares Outstanding without Project & 100.00 & 100.00 & 100.00 & 100.00 & 100.00 & 100.00 & 100.00 & 100.00 & 100.00 & 100.00 & 100.00 & 100.00 & 100.00 & 100.00 & 100.00 & 100.00 \\
\hline 16) & Initial Value of Equity without Project & 80.14 & 80.14 & 80.14 & 80.14 & 80.14 & 80.14 & 80.14 & 80.14 & 80.14 & 80.14 & 80.14 & 80.14 & 80.14 & 80.14 & 80.14 & 80.14 \\
\hline 17) & Total Shares Outstanding with Project & 120.33 & 120.08 & 119.77 & 119.42 & 119.03 & 118.61 & 118.16 & 117.70 & 117.22 & 116.74 & 116.26 & 115.80 & 115.34 & 114.91 & 114.49 & 114.10 \\
\hline 18) & Initial Value of Equity with Project & 97.70 & 97.33 & 96.91 & 96.44 & 95.92 & 95.37 & 94.80 & 94.21 & 93.60 & 92.99 & 92.37 & 91.76 & 91.14 & 90.54 & 89.94 & 89.35 \\
\hline 19) & $\Delta$ Value of Original Equity & $\$ 1.05$ & $\$ 0.92$ & $\$ 0.77$ & $\$ 0.61$ & $\$ 0.44$ & $\$ 0.27$ & $\$ 0.09$ & $-\$ 0.10$ & $-\$ 0.29$ & $-\$ 0.49$ & $-\$ 0.69$ & $-\$ 0.90$ & $-\$ 1.12$ & $-\$ 1.35$ & $-\$ 1.59$ & $-\$ 1.83$ \\
\hline 20) & $\Delta$ Value of Original Equity: Tax Rate $=0$ & $-\$ 0.40$ & $-\$ 0.49$ & $-\$ 0.59$ & $-\$ 0.69$ & $-\$ 0.78$ & $-\$ 0.88$ & $-\$ 0.97$ & $-\$ 1.06$ & $-\$ 1.14$ & $-\$ 1.23$ & $-\$ 1.31$ & $-\$ 1.40$ & $-\$ 1.49$ & $-\$ 1.59$ & $-\$ 1.69$ & $-\$ 1.80$ \\
\hline 21) & $\triangle$ Value of Original Equity: $B C=0$ & $\$ 0.90$ & $\$ 0.92$ & $\$ 0.95$ & $\$ 0.99$ & $\$ 1.03$ & $\$ 1.09$ & $\$ 1.16$ & $\$ 1.25$ & $\$ 1.33$ & $\$ 1.43$ & $\$ 1.53$ & $\$ 1.64$ & $\$ 1.74$ & $\$ 1.85$ & $\$ 1.96$ & $\$ 2.07$ \\
\hline 22) & $\triangle$ Value of Original Equity: Tax Rate $\& B C=0$ & $-\$ 0.42$ & $-\$ 0.33$ & $-\$ 0.21$ & $-\$ 0.08$ & $\$ 0.08$ & $\$ 0.25$ & $\$ 0.44$ & $\$ 0.64$ & $\$ 0.86$ & $\$ 1.09$ & $\$ 1.32$ & $\$ 1.56$ & $\$ 1.81$ & $\$ 2.06$ & $\$ 2.30$ & $\$ 2.54$ \\
\hline \multicolumn{18}{|c|}{ Value of Tax Shields } \\
\hline 23) & Total Value of Tax Shields & $\$ 6.30$ & $\$ 6.30$ & $\$ 6.30$ & $\$ 6.30$ & $\$ 6.30$ & $\$ 6.30$ & $\$ 6.30$ & $\$ 6.30$ & $\$ 6.30$ & $\$ 6.30$ & $\$ 6.30$ & $\$ 6.30$ & $\$ 6.30$ & $\$ 6.30$ & $\$ 6.30$ & $\$ 6.30$ \\
\hline 24) & Total Value of Tax Shields with Project & $\$ 7.76$ & $\$ 7.72$ & $\$ 7.66$ & $\$ 7.60$ & $\$ 7.53$ & $\$ 7.45$ & $\$ 7.36$ & $\$ 7.25$ & $\$ 7.14$ & $\$ 7.03$ & $\$ 6.90$ & $\$ 6.77$ & $\$ 6.63$ & $\$ 6.49$ & $\$ 6.34$ & $\$ 6.19$ \\
\hline 25) & Change in Value of Tax Shields & $\$ 1.46$ & $\$ 1.41$ & $\$ 1.36$ & $\$ 1.30$ & $\$ 1.23$ & $\$ 1.14$ & $\$ 1.05$ & $\$ 0.95$ & $\$ 0.84$ & $\$ 0.72$ & $\$ 0.60$ & $\$ 0.47$ & $\$ 0.33$ & $\$ 0.18$ & $\$ 0.04$ & $-\$ 0.12$ \\
\hline \multicolumn{18}{|c|}{ Bankruptcy Costs } \\
\hline 26) & Bankruptcy Costs without Project & $\$ 3.69$ & $\$ 3.69$ & $\$ 3.69$ & $\$ 3.69$ & $\$ 3.69$ & $\$ 3.69$ & $\$ 3.69$ & $\$ 3.69$ & $\$ 3.69$ & $\$ 3.69$ & $\$ 3.69$ & $\$ 3.69$ & $\$ 3.69$ & $\$ 3.69$ & $\$ 3.69$ & $\$ 3.69$ \\
\hline 27$)$ & Bankruptcy Costs with Project & $\$ 2.66$ & $\$ 3.09$ & $\$ 3.58$ & $\$ 4.12$ & $\$ 4.71$ & $\$ 5.33$ & $\$ 5.97$ & $\$ 6.63$ & $\$ 7.30$ & $\$ 7.96$ & $\$ 8.63$ & $\$ 9.28$ & $\$ 9.93$ & $\$ 10.56$ & $\$ 11.18$ & $\$ 11.78$ \\
\hline 28) & Change in Bankruptcy Costs & $-\$ 1.03$ & $-\$ 0.60$ & $-\$ 0.11$ & $\$ 0.43$ & $\$ 1.02$ & $\$ 1.64$ & $\$ 2.28$ & $\$ 2.94$ & $\$ 3.61$ & $\$ 4.27$ & $\$ 4.94$ & $\$ 5.59$ & $\$ 6.24$ & $\$ 6.87$ & $\$ 7.49$ & $\$ 8.09$ \\
\hline \multicolumn{18}{|c|}{ Impact of Project on Manager } \\
\hline 29) & Change in Managers Utility From Z & 0.0321 & 0.0264 & 0.0197 & 0.0119 & 0.0030 & -0.0069 & -0.0178 & -0.0298 & -0.0428 & -0.0568 & -0.0719 & -0.0879 & -0.1050 & -0.1230 & -0.1420 & -0.1618 \\
\hline 30) & Change in Managers Utility From Zero NPV Project with No Options & 0.0361 & 0.0289 & 0.0205 & 0.0111 & 0.0007 & -0.0108 & -0.0234 & -0.0375 & -0.0536 & -0.0726 & -0.0955 & -0.1235 & -0.1576 & -0.1985 & -0.2462 & -0.3006 \\
\hline \multicolumn{18}{|c|}{ 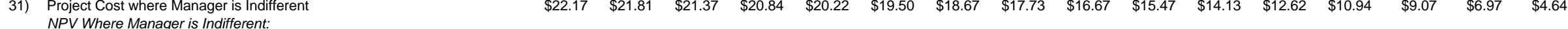 } \\
\hline 32) & Base Case & $-\$ 2.17$ & $-\$ 1.81$ & $-\$ 1.37$ & $-\$ 0.84$ & $-\$ 0.22$ & $\$ 0.50$ & $\$ 1.33$ & $\$ 2.27$ & $\$ 3.33$ & $\$ 4.53$ & $\$ 5.87$ & $\$ 7.38$ & $\$ 9.06$ & $\$ 10.93$ & $\$ 13.03$ & $\$ 15.36$ \\
\hline 33) & Tax Rate $=0$ & $-\$ 0.62$ & $-\$ 0.32$ & $\$ 0.05$ & $\$ 0.48$ & $\$ 0.99$ & $\$ 1.57$ & $\$ 2.23$ & $\$ 2.98$ & $\$ 3.83$ & $\$ 4.79$ & $\$ 5.86$ & $\$ 7.06$ & $\$ 8.41$ & $\$ 9.92$ & $\$ 11.60$ & $\$ 13.48$ \\
\hline 34$)$ & $B C=0$ & $-\$ 1.85$ & $-\$ 1.67$ & $-\$ 1.45$ & $-\$ 1.17$ & $-\$ 0.84$ & $-\$ 0.44$ & $\$ 0.03$ & $\$ 0.57$ & $\$ 1.20$ & $\$ 1.93$ & $\$ 2.75$ & $\$ 3.69$ & $\$ 4.75$ & $\$ 5.94$ & $\$ 7.27$ & $\$ 8.76$ \\
\hline 35) & $B C \&$ Tax Rate $=0$ & $-\$ 0.42$ & $-\$ 0.35$ & $-\$ 0.24$ & $-\$ 0.09$ & $\$ 0.09$ & $\$ 0.33$ & $\$ 0.62$ & $\$ 0.97$ & $\$ 1.39$ & $\$ 1.89$ & $\$ 2.47$ & $\$ 3.15$ & $\$ 3.94$ & $\$ 4.84$ & $\$ 5.86$ & $\$ 7.03$ \\
\hline 36) & Risk Neutral Manager, $B C \&$ Tax Rate $=0$ & $\$ 2.00$ & $\$ 1.50$ & $\$ 0.95$ & $\$ 0.34$ & $-\$ 0.31$ & $-\$ 1.00$ & $-\$ 1.72$ & $-\$ 2.47$ & $-\$ 3.24$ & $-\$ 4.02$ & $-\$ 4.81$ & $-\$ 5.61$ & $-\$ 6.42$ & $-\$ 7.23$ & $-\$ 8.03$ & $-\$ 8.84$ \\
\hline \multicolumn{18}{|c|}{$\begin{array}{l}\text { Incremental Cost of Equity Where Manager is Indifferent: } \\
\text { In lisk }\end{array}$} \\
\hline 38) & Base Case & $-0.66 \%$ & $-0.56 \%$ & $-0.43 \%$ & $-0.27 \%$ & $-0.07 \%$ & $0.17 \%$ & $0.48 \%$ & $0.86 \%$ & $1.34 \%$ & $1.96 \%$ & $2.78 \%$ & $3.91 \%$ & $5.54 \%$ & $8.08 \%$ & $12.52 \%$ & $22.17 \%$ \\
\hline 39) & Tax Rate $=0$ & $-0.21 \%$ & $-0.11 \%$ & $0.02 \%$ & $0.17 \%$ & $0.36 \%$ & $0.59 \%$ & $0.86 \%$ & $1.21 \%$ & $1.63 \%$ & $2.17 \%$ & $2.85 \%$ & $3.76 \%$ & $4.99 \%$ & $6.77 \%$ & $9.51 \%$ & $14.24 \%$ \\
\hline 40) & $B C=0$ & $-0.56 \%$ & $-0.51 \%$ & $-0.45 \%$ & $-0.37 \%$ & $-0.27 \%$ & $-0.14 \%$ & $0.01 \%$ & $0.20 \%$ & $0.43 \%$ & $0.71 \%$ & $1.07 \%$ & $1.51 \%$ & $2.08 \%$ & $2.82 \%$ & $3.81 \%$ & $5.20 \%$ \\
\hline 41$)$ & $B C \&$ Tax Rate $=0$ & $-0.14 \%$ & $-0.11 \%$ & $-0.08 \%$ & $-0.03 \%$ & $0.03 \%$ & $0.11 \%$ & $0.21 \%$ & $0.34 \%$ & $0.50 \%$ & $0.70 \%$ & $0.95 \%$ & $1.26 \%$ & $1.65 \%$ & $2.15 \%$ & $2.79 \%$ & $3.65 \%$ \\
\hline 42) & Risk Neutral Manager, BC \& Tax & $0.75 \%$ & $0.55 \%$ & $0.33 \%$ & $0.12 \%$ & $-0.10 \%$ & $-0.32 \%$ & $-0.53 \%$ & $-0.74 \%$ & $-0.94 \%$ & $-1.13 \%$ & $-1.30 \%$ & $-1.47 \%$ & $-1.63 \%$ & $-1.79 \%$ & $-1.93 \%$ & $-2.06 \%$ \\
\hline 43) & Risk Neutral Manager Owns No Options, $B C \&$ Tax Rate $=0$ & $0.15 \%$ & $0.12 \%$ & $0.08 \%$ & $0.03 \%$ & $-0.03 \%$ & $-0.09 \%$ & $-0.15 \%$ & $-0.22 \%$ & $-0.29 \%$ & $-0.37 \%$ & $-0.44 \%$ & $-0.52 \%$ & $-0.59 \%$ & $-0.67 \%$ & $-0.74 \%$ & $-0.81 \%$ \\
\hline
\end{tabular}




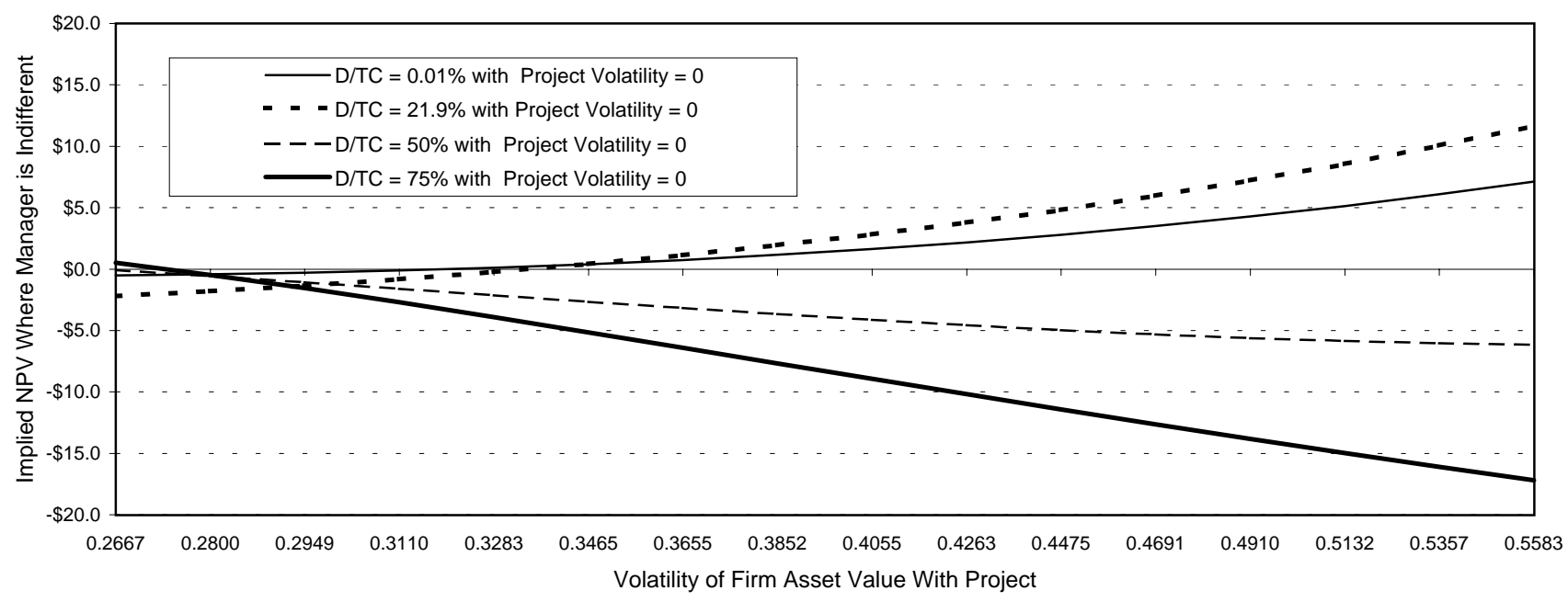

Figure 1a. Implied NPV where the manager is indifferent for different values of firm asset value volatility with the project and where the market debt/equity ratio for the project financing equals the market debt/equity ratio before the project is adopted.

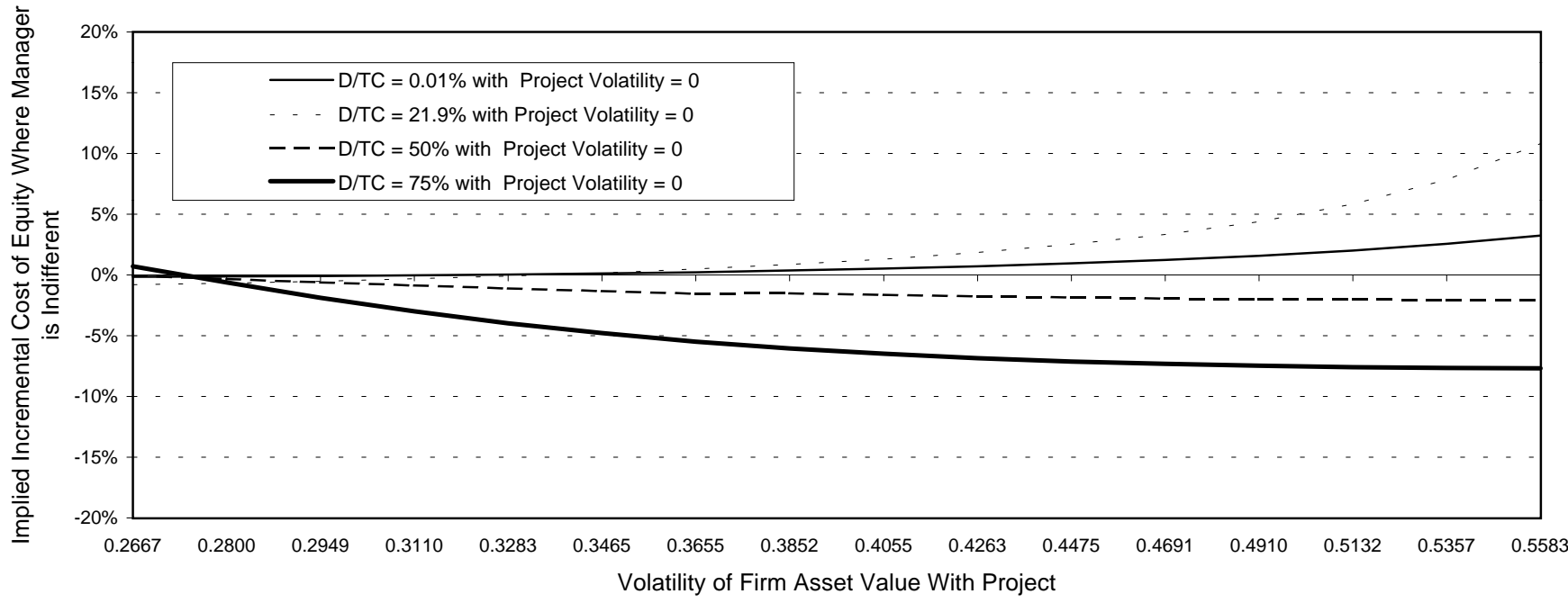

Figure 1b. Implied incremental cost of equity where manager is indifferent for different values of firm asset value volatility with the project and where the market debt/equity ratio for the project financing equals the market debt/equity ratio before the project is adopted. 


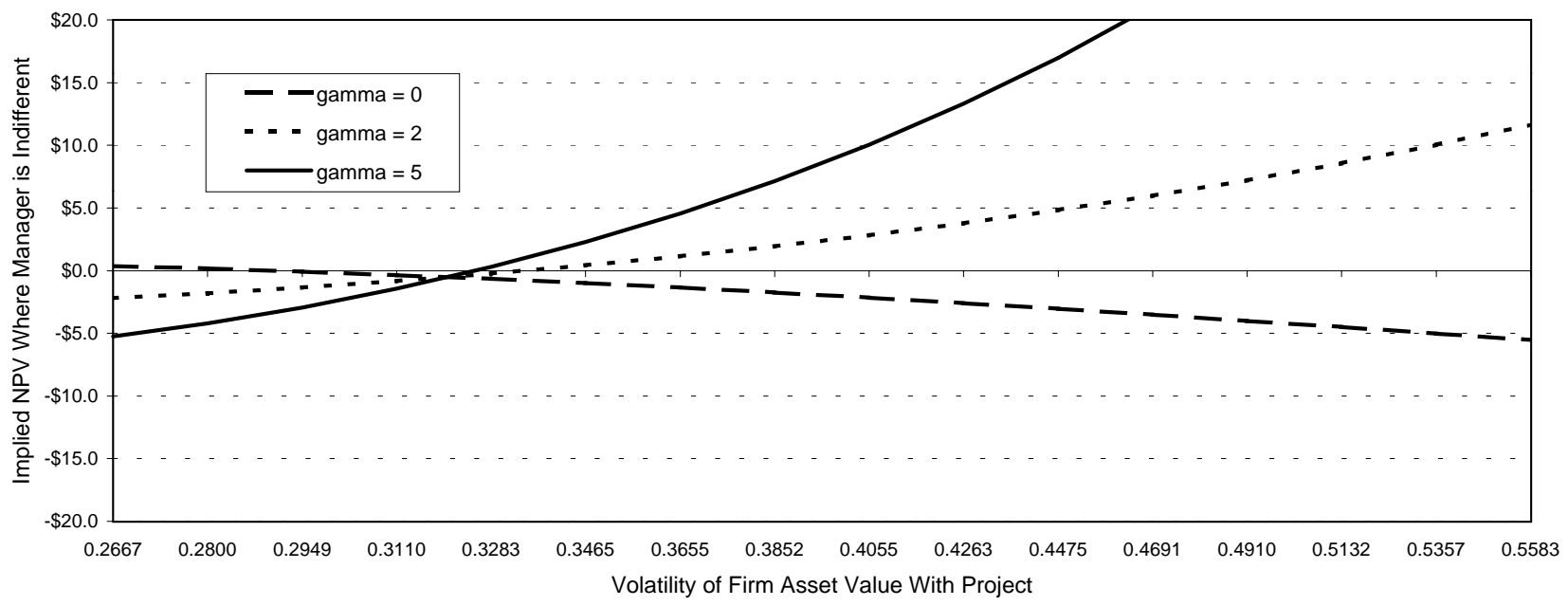

Figure 2a. Implied NPV where manager is indifferent for different values of firm asset value volatility with the project and where the market debt/equity ratio for the project financing equals the market debt/equity ratio before the project is adopted.

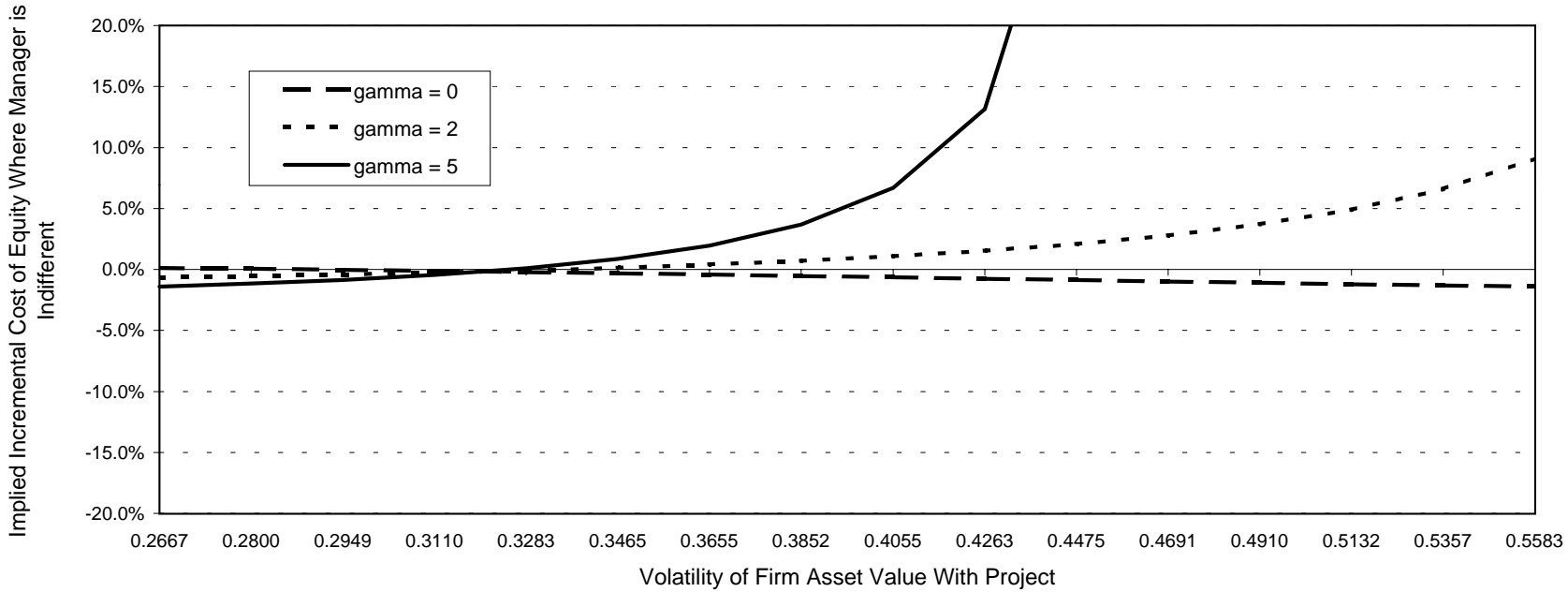

Figure 2b. Implied incremental cost of equity where manager is indifferent for different values of firm asset value volatility with the project and where the market debt/equity ratio for the project financing equals the market debt/equity ratio before the project is adopted. 


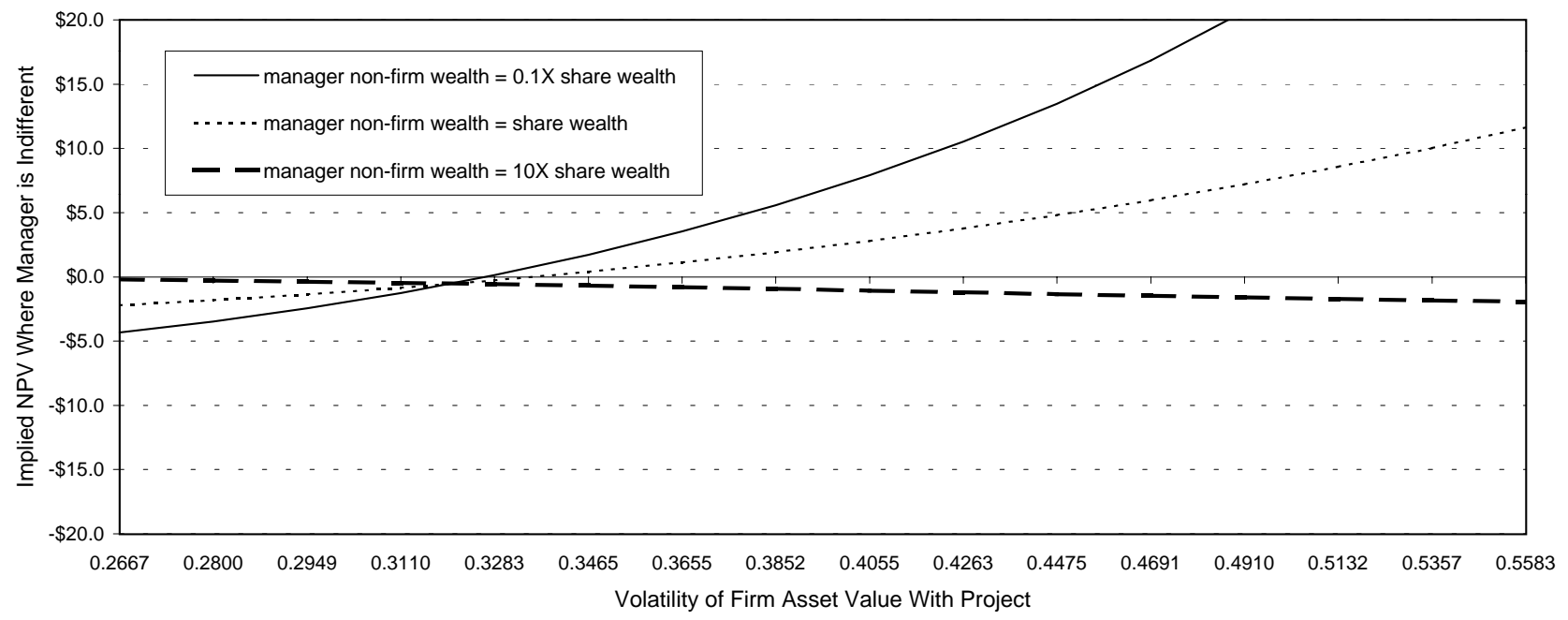

Figure 3a. Implied NPV where manager is indifferent for different values of firm asset value volatility with the project and where the market debt/equity ratio for the project financing equals the market debt/equity ratio before the project is adopted.

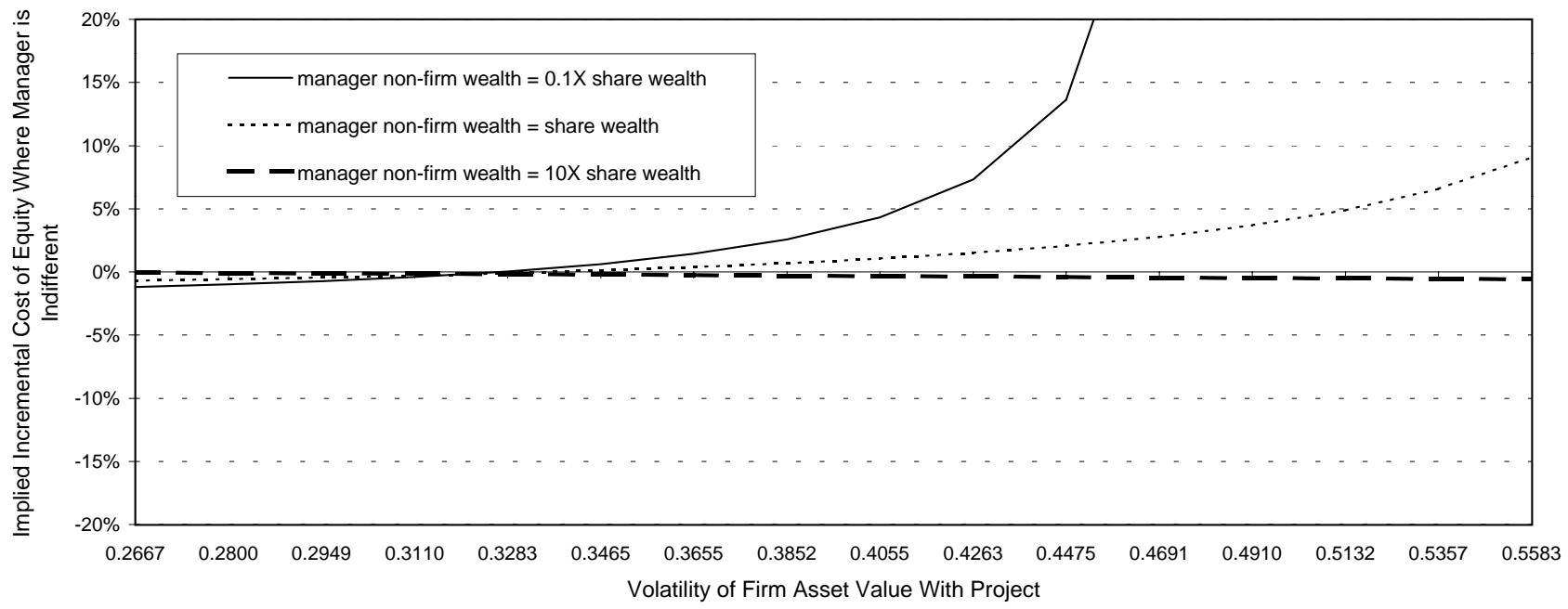

Figure 3b. Implied incremental cost of equity where manager is indifferent for different values of firm asset value volatility with the project and where the market debt/equity ratio for the project financing equals the market debt/equity ratio before the project is adopted. 


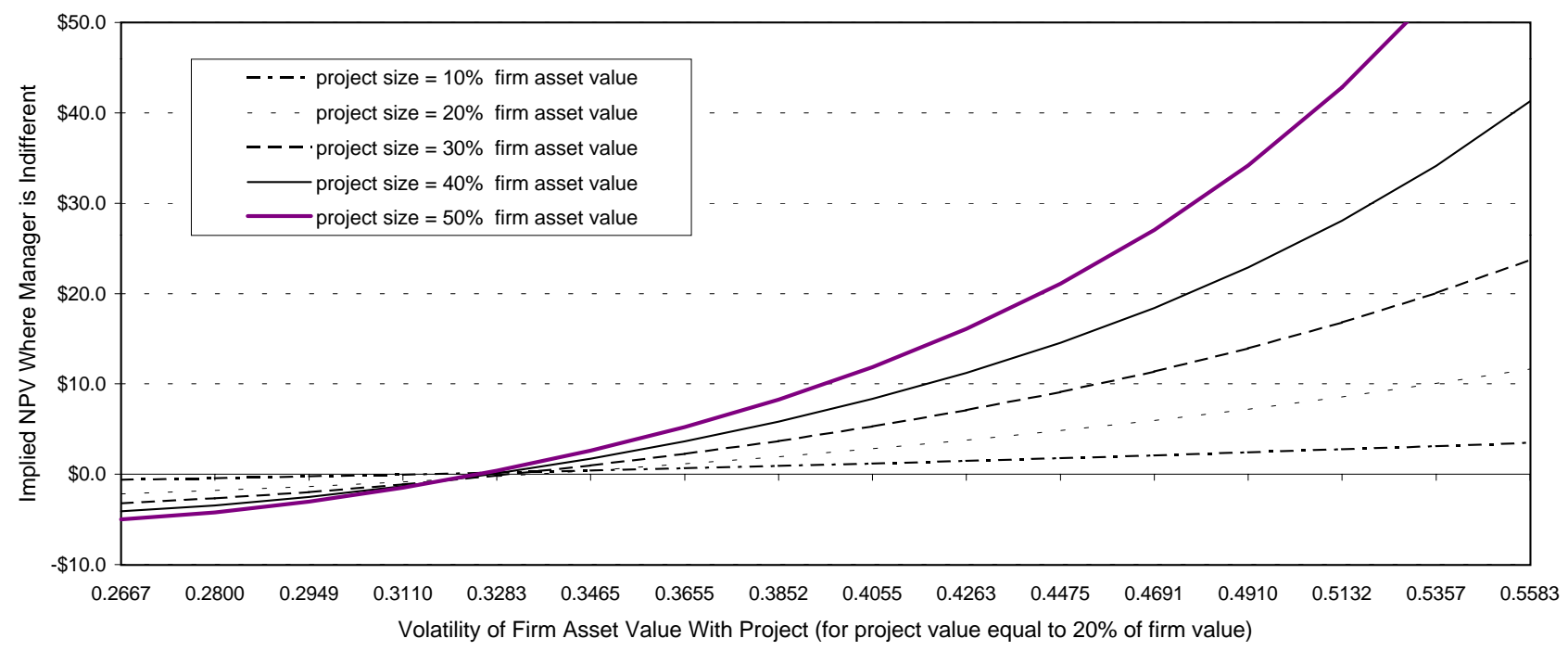

Figure 4a. Implied NPV where manager is indifferent for different values of firm asset value volatility with the project and where the market debt/equity ratio for the project financing equals the market debt/equity ratio before the project is adopted.

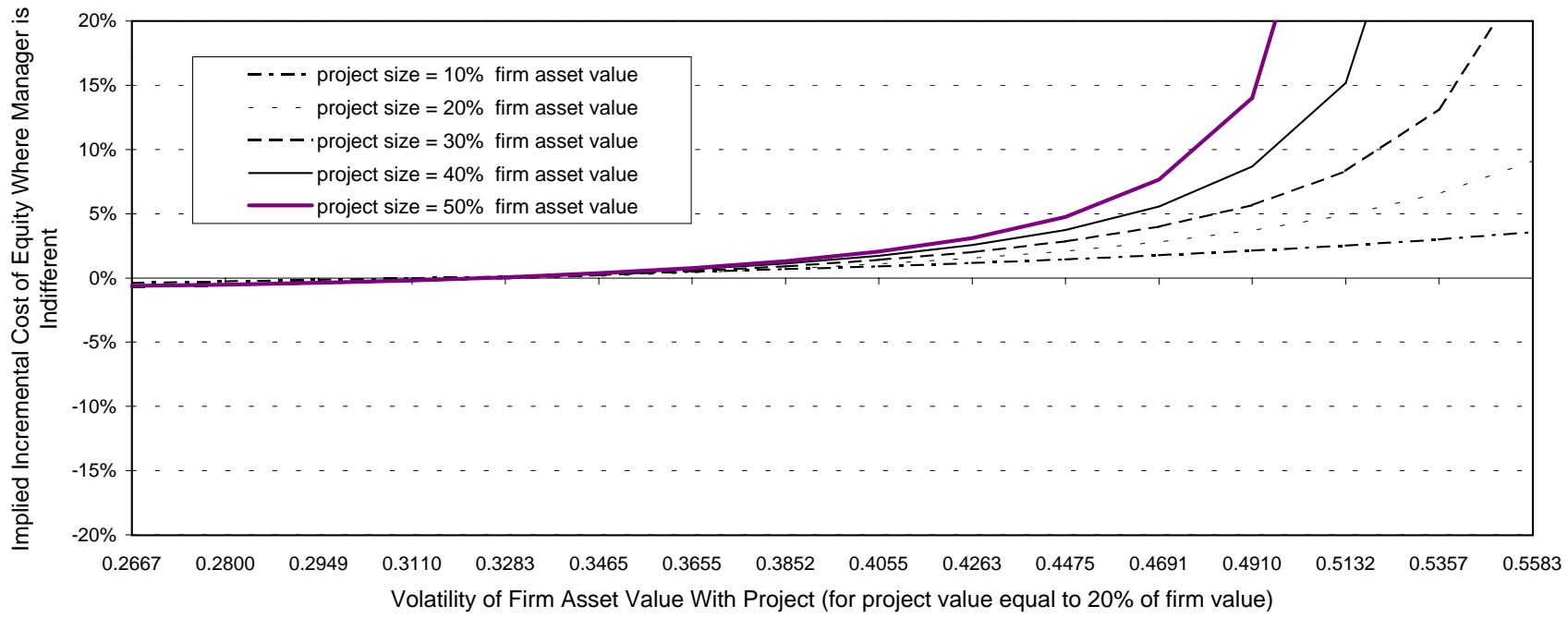

Figure 4b. Implied incremental cost of equity where manager is indifferent for different values of firm asset value volatility with the project and where the market debt/equity ratio for the project financing equals the market debt/equity ratio before the project is adopted. 


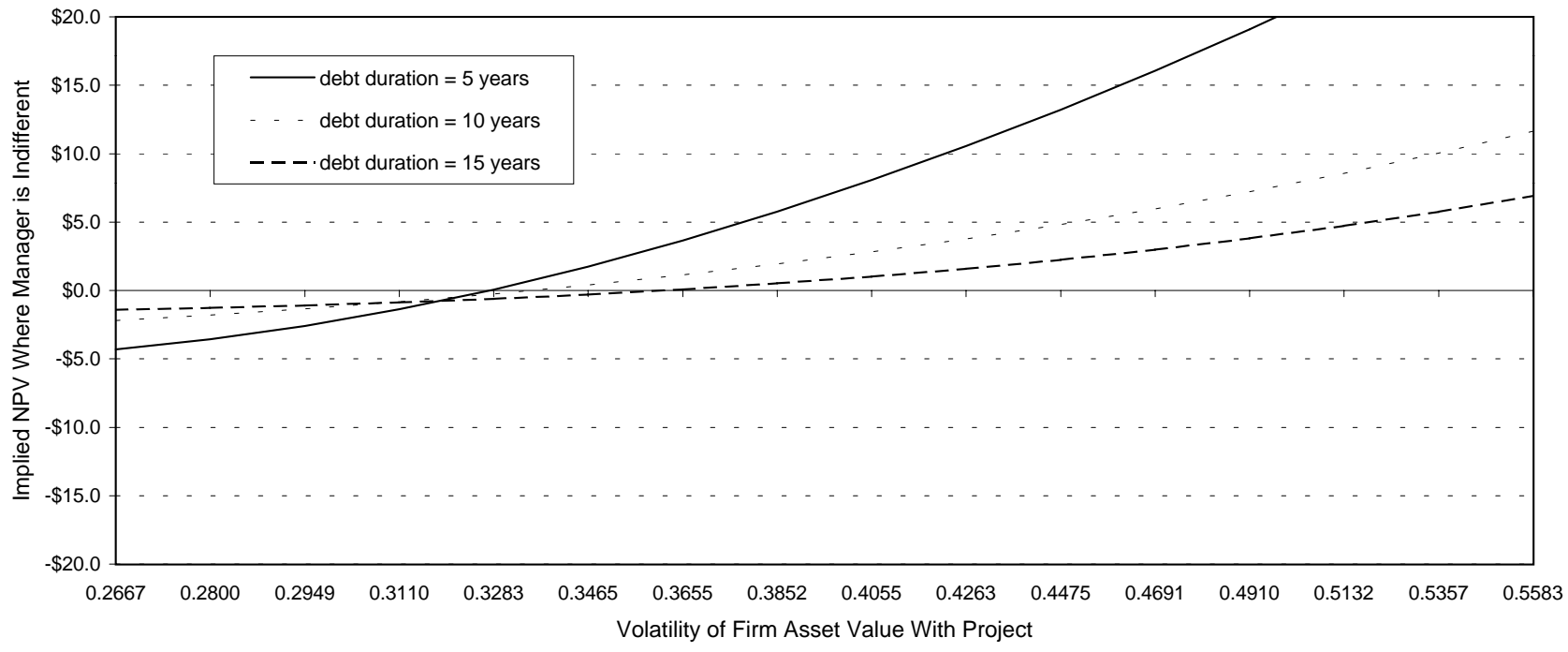

Figure 5a. Implied NPV where manager is indifferent for different values of firm asset value volatility with the project and where the market debt/equity ratio for the project financing equals the market debt/equity ratio before the project is adopted.

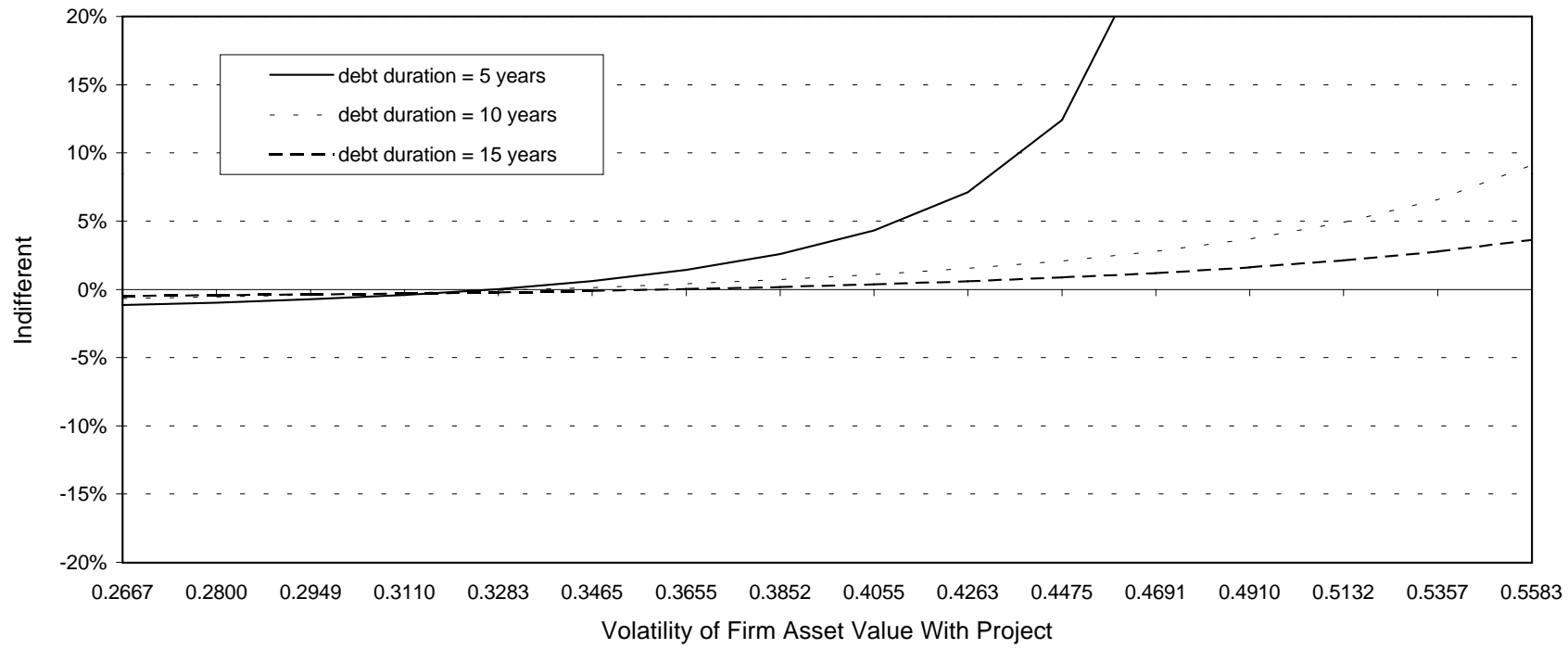

Figure 5b. Implied incremental cost of equity where manager is indifferent for different values of firm asset value volatility with the project and where the market debt/equity ratio for the project financing equals the market debt/equity ratio before the project is adopted. 


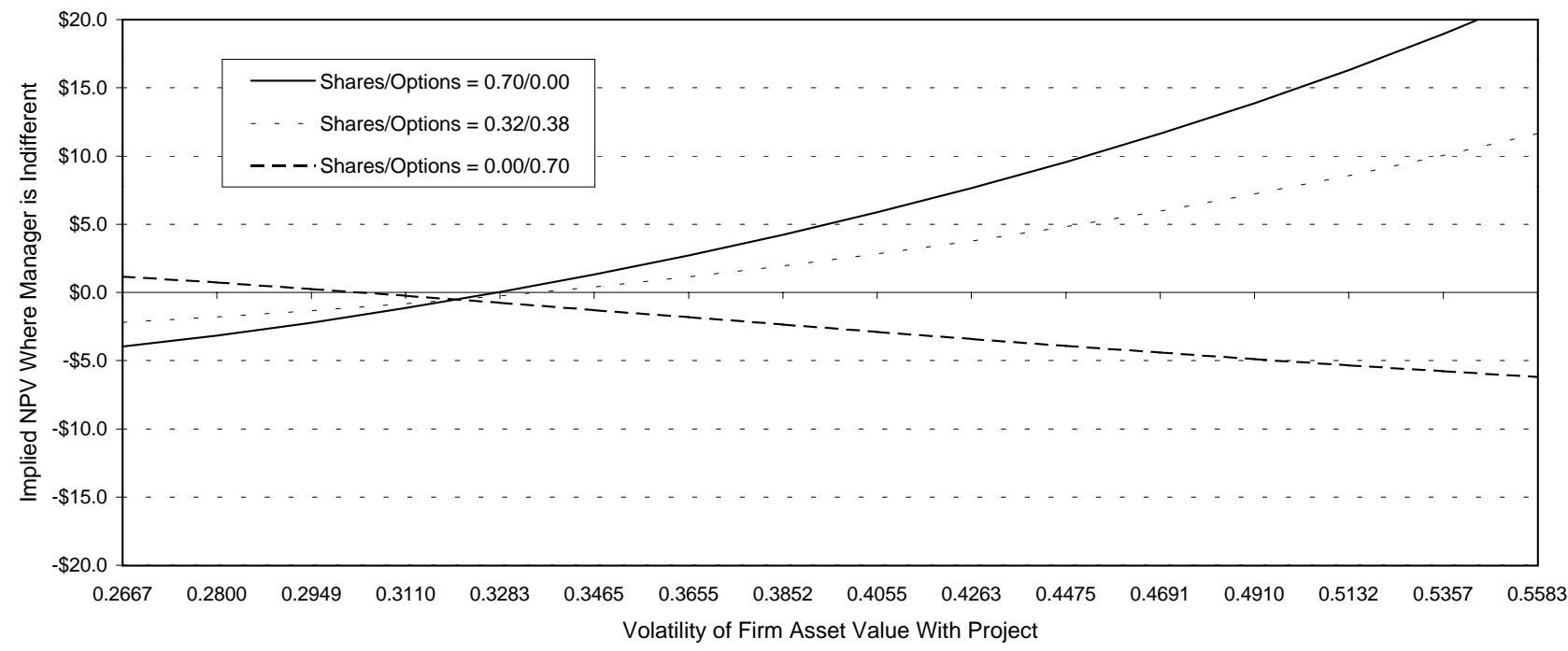

Figure 6a. Implied NPV where manager is indifferent for different values of firm asset value volatility with the project and where the market debt/equity ratio for the project financing equals the market debt/equity ratio before the project is adopted.

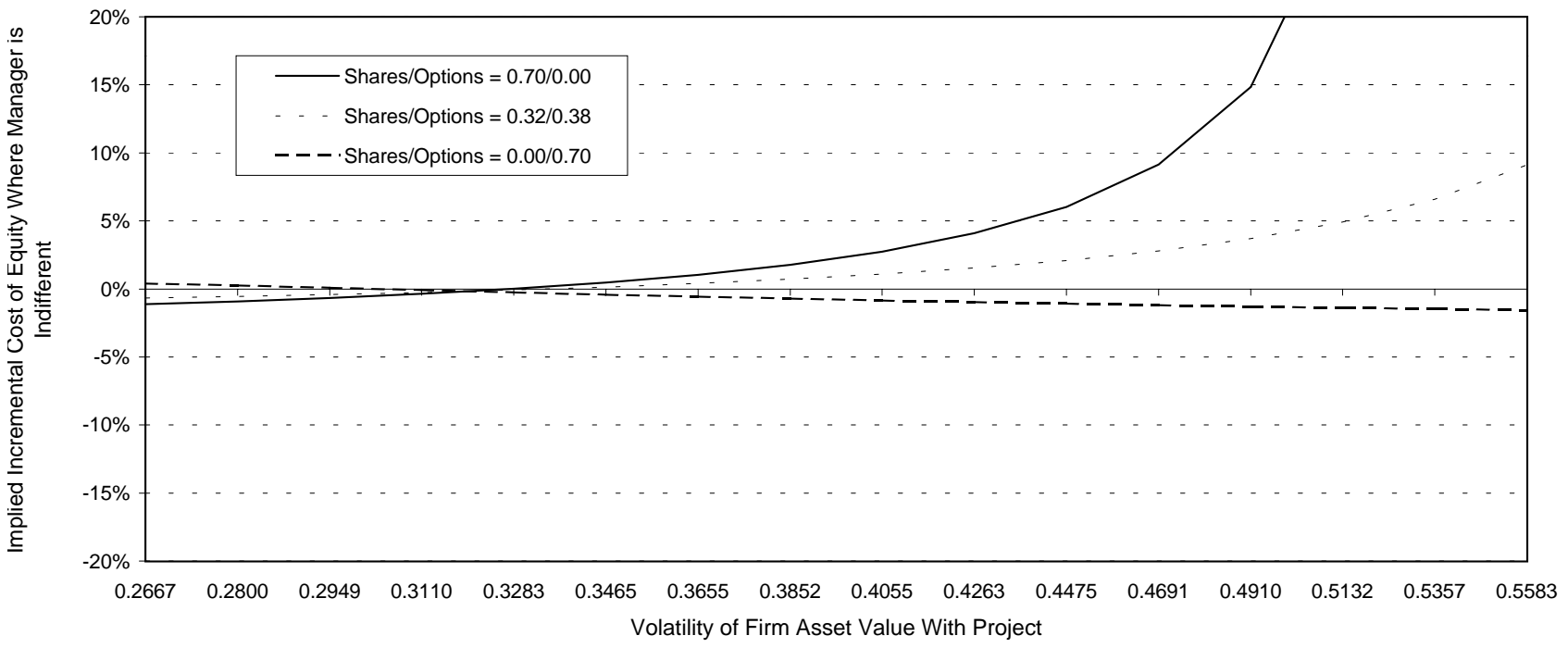

Figure 6b. Implied incremental cost of equity where manager is indifferent for different values of firm asset value volatility with the project and where the market debt/equity ratio for the project financing equals the market debt/equity ratio before the project is adopted. 


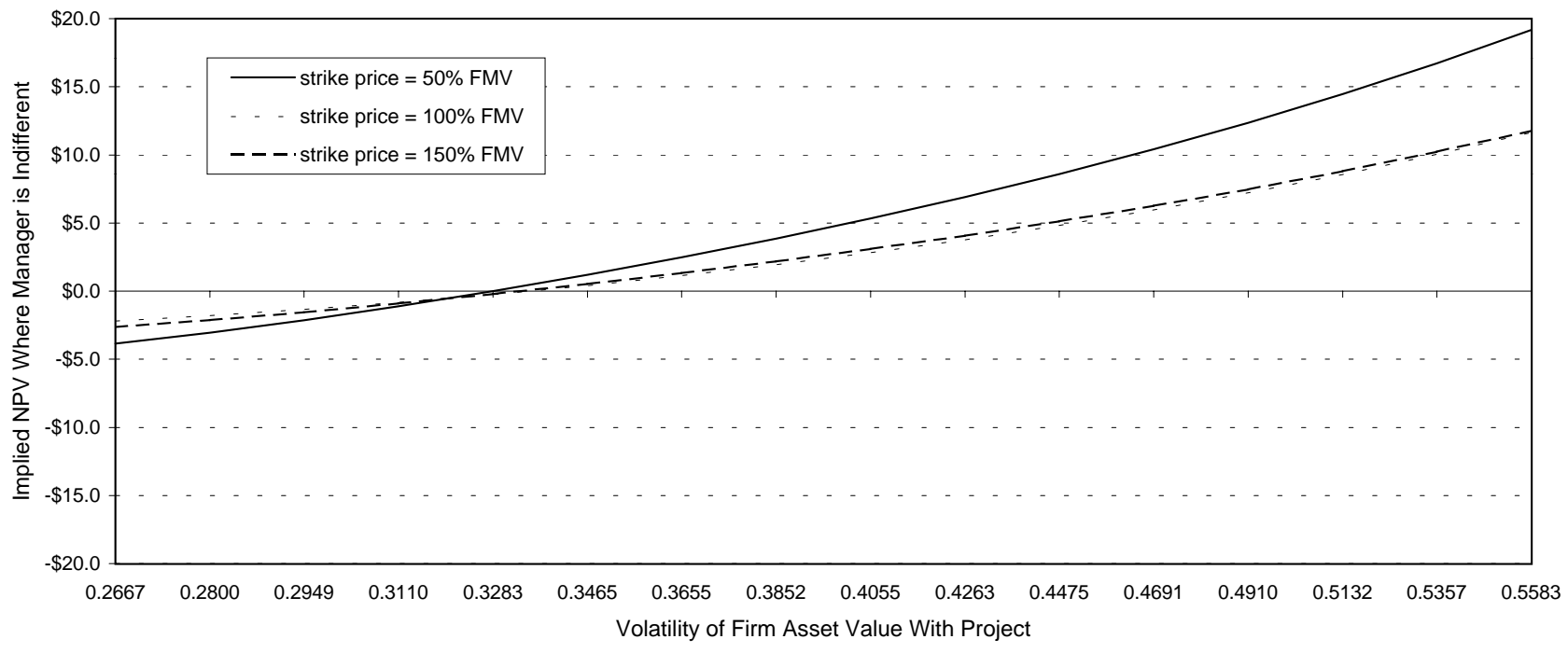

Figure 7a. Implied NPV where manager is indifferent for different values of firm asset value volatility with the project and where the market debt/equity ratio for the project financing equals the market debt/equity ratio before the project is adopted.

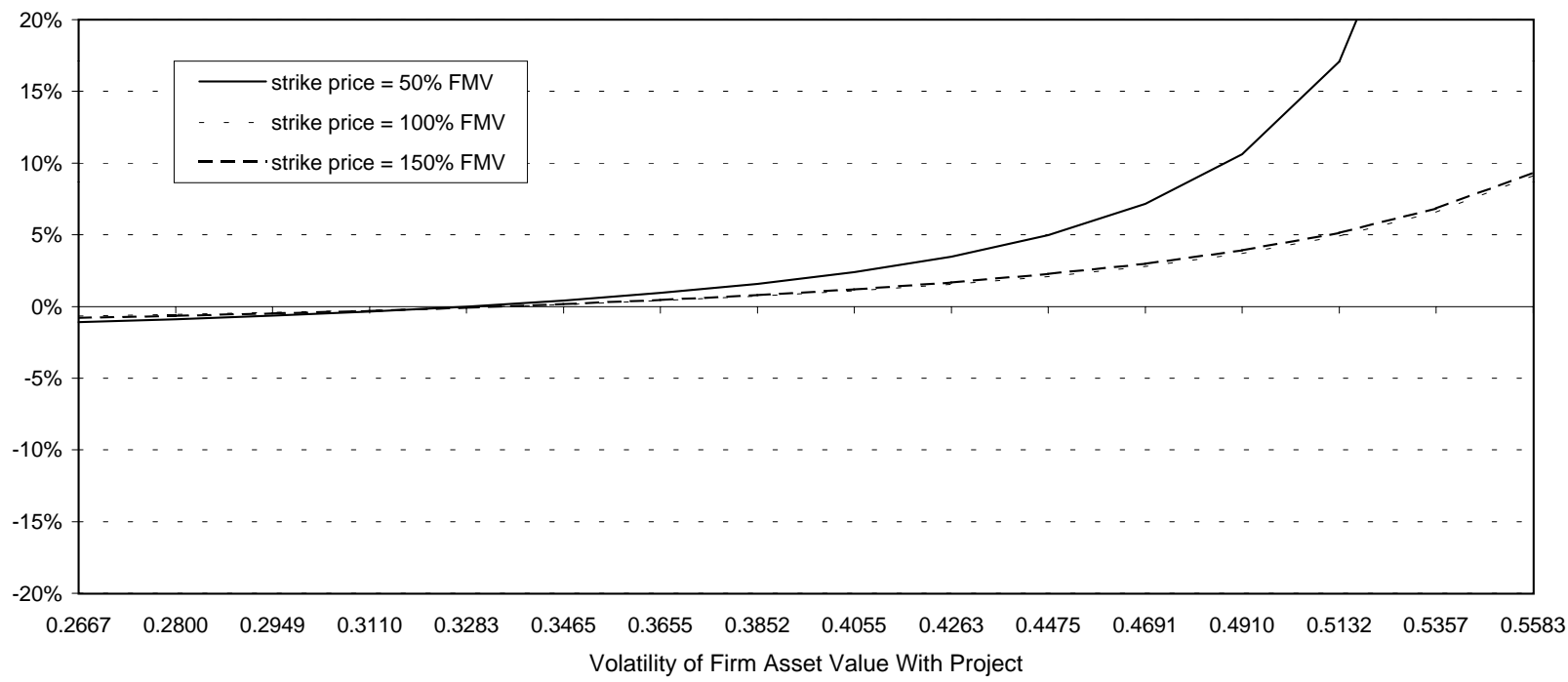

Figure 7b. Implied incremental cost of equity where manager is indifferent for different values of firm asset value volatility with the project and where the market debt/equity ratio for the project financing equals the market debt/equity ratio before the project is adopted. 


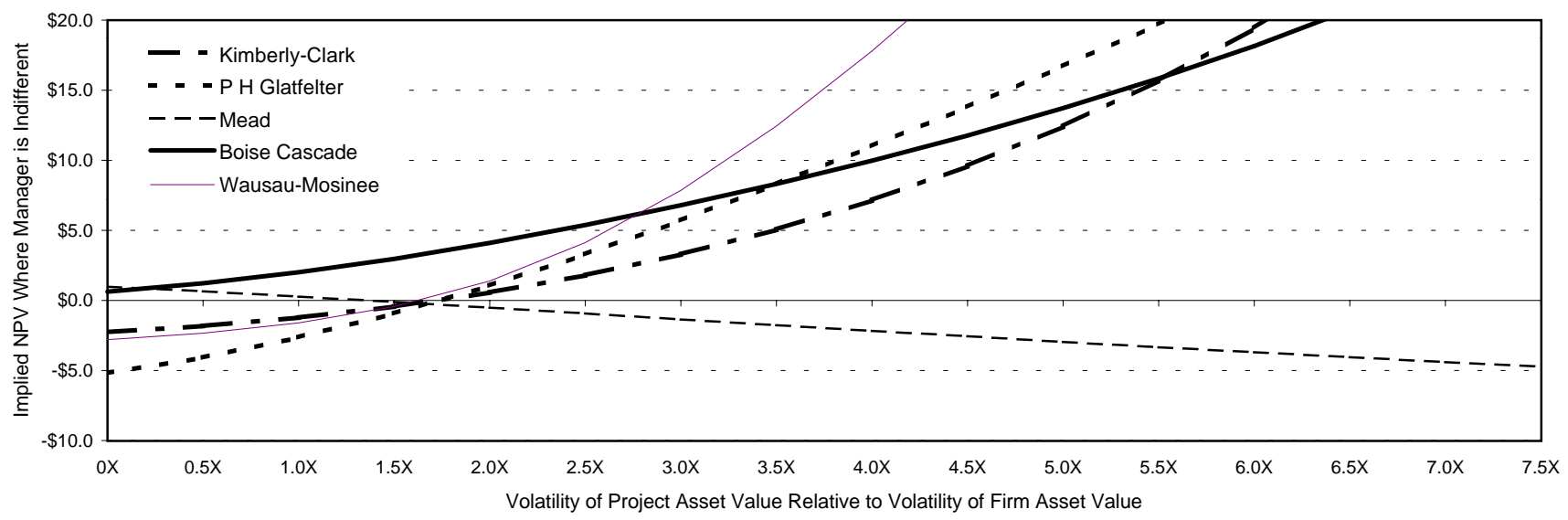

Figure 8a. Paper and Allied Product Manufacturing Firms. Implied NPV where the manager is indifferent for different values of project volatility and where the market debt/equity ratio for the project financing equals the market debt/equity ratio before the project is adopted.

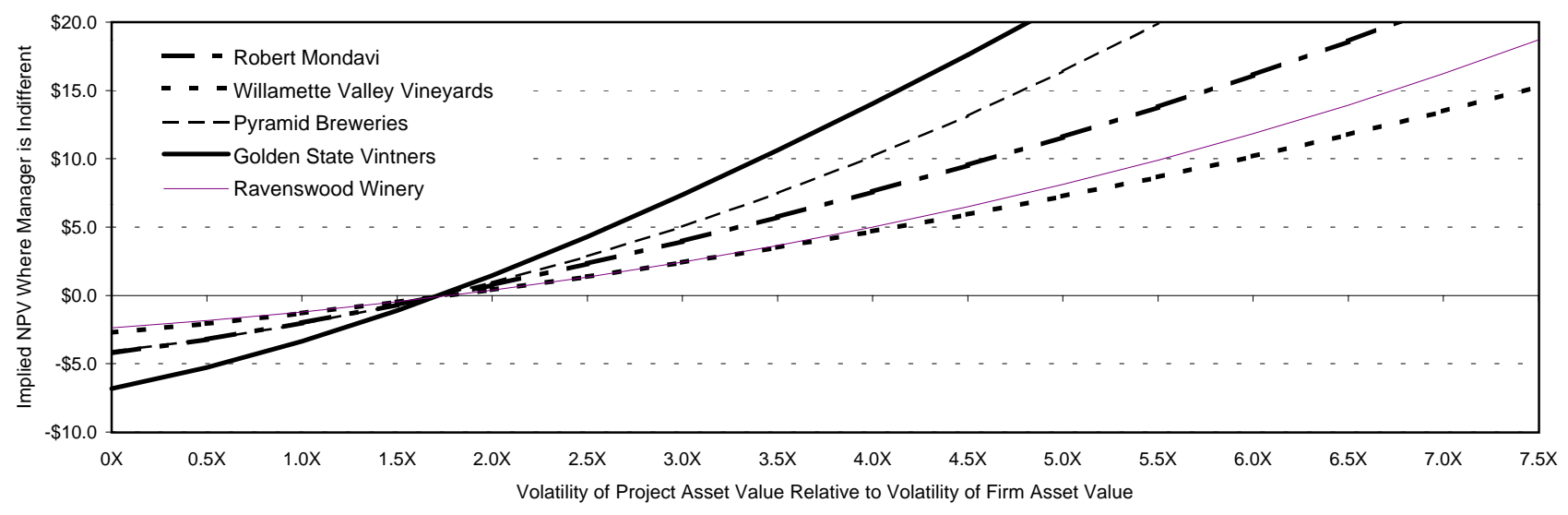

Figure 8b. Beer and Wine Manufacturing Firms. Implied NPV where the manager is indifferent for different values of project volatility and where the market debt/equity ratio for the project financing equals the market debt/equity ratio before the project is adopted.

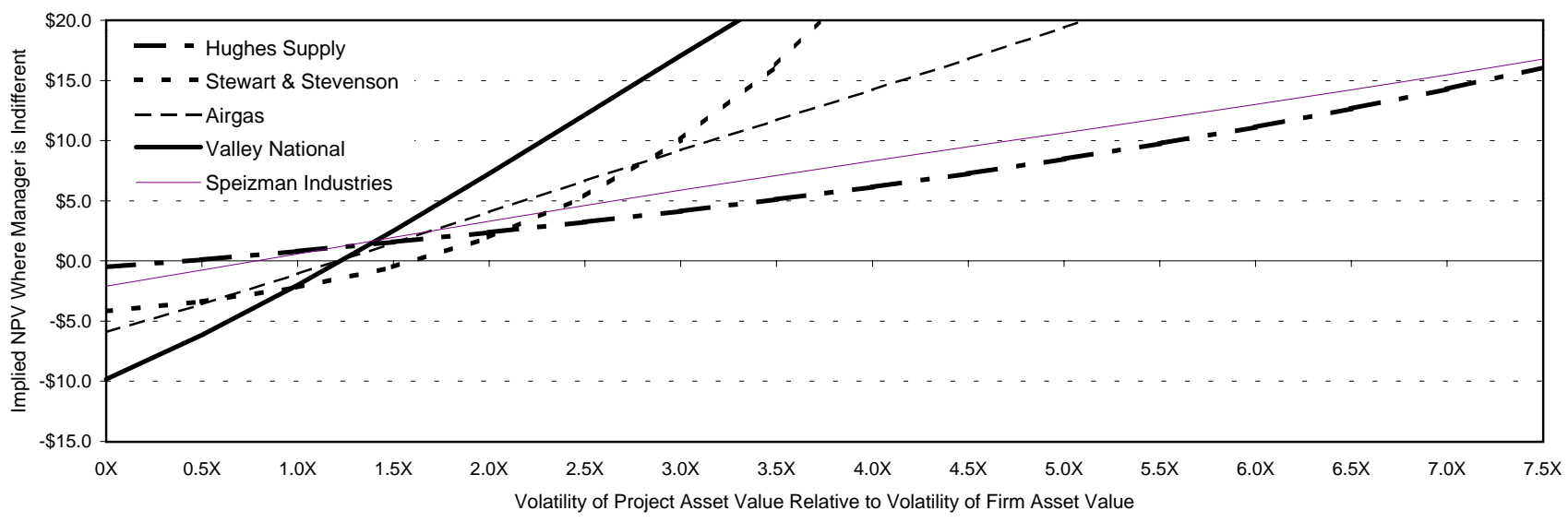

Figure 8c. Wholesale Distribution Firms. Implied NPV where the manager is indifferent for different values of project volatility and where the market debt/equity ratio for the project financing equals the market debt/equity ratio before the project is adopted. 